\title{
Nudibranch life cycles in the Northwest Atlantic and their relationship to the ecology of fouling communities*
}

\author{
K. B. Clark \\ University of Connecticut Marine Research Laboratory; \\ Noank, Connecticut, USA
}

KURZFASSUNG: Lebenszyklen von Nudibranchiern aus dem Nordost-Atlantik und ihre Beziehung zur Okologie von Aufwuchsorganismen. Die Lebenszyklen zahlreicher Nudibranchia- und Saccoglossa-Arten (Gastropoda) aus dem Nordwest-Atlantik werden vergleichend untersucht. Die meisten Species (Vertreter der Aeolidia und Saccoglossa) erzeugen zwei oder mehrere; sich uberlappende Generationen pro Jahr. Sie werden früher geschlechtsreif und sind durch kontinuierliche Eiproduktion, rasches Wachstum, geringe Maximalgröße und hohe Stoffwechselintensitäten charakterisiert. Außerdem besitzen sie Dorsalpapillen mit Leberdivertikeln (Cerata) und ernähren sich ron Hydroiden und Algen, die charakteristische Glieder früher Stadien der Aufwuchs-Lebensgemeinschaften darstellen. Eine kleinere Gruppe von Species (vorwiegend Doridacea) umfaßt dagegen Formen, die jährlich nur einmal Nachkommen hervorbringen sowie größere Körpermaße und relativ niedrigere Stoffwechselraten aufweisen. Sie ernähren sich vorwiegend von Bryozoen, deren Auftreten in der Artensukzession späte Stadien dieser Lebensgemeinschaften kennzeichnet. Verschiedene populationsdynamische Aspekte werden erörtert. Für das plötzliche Verschwinden der einzelnen Populationen sind mehrere Faktoren verantwortlich. Die kleineren Formen können bestimmte Mikrohabitate durch zu starkes Abweiden zerstören, während die größeren Formen bei der sehr rasch sich vollziehenden, totalen Entleerung der Geschlechtsprodukte zugrunde gehen. Das of beobachtete unvermittelte Erscheinen derartiger Populationen beruht auf dem Auftreten zahlreicher, metamorphosebereiter Larven und dem raschen Wachstum der Jungtiere. Möglicherweise hängt auch das Ansetzen und die Metamorphose der Larven von dem Erreichen eines kritischen Temperaturniveaus $a b$. Die hohe Temperaturempfindlichkeit der meisten Nudibranchia erklärt, weshalb sie im Artenspektrum der Litoralfauna des Nordwest-Atlantik, wo beträchtliche Temperatur-Unterschiede auftreten, einen relativ geringen Anteil haben.

\section{INTRODUCTION}

Despite an increasing volume of research on the biology of nudibranchiate molluscs, several interrelated ecological problems remain unsolved. Sudden, dramatic population changes have been reported for populations of Nudibranchia, and the ecologically similar nudibranchiate Sacoglossa, by many authors (Alder \& HANCock,

* Contribution number 100 of the Marine Research Laboratory. 
1845; Balch, 1908; Chambers, 1934; Costello, 1938; Swennen, 1961 ; Miller, 1962 ; Thompson, 1964; Nrbakken, 1974). The mechanism and significance of these fluctuations, however, have not been identified.

Extreme feeding specificity characterizes the Nudibranchia and Sacoglossa, with feeding frequently limited to a single prey species (THOMpson, 1964). As SwENNEN (1959) noted, the relationship of nudibranchs to their prey species (usually fouling organisms) often approaches ectoparasitism. Hence, the effect of population surges on the ecology of fouling communities may be considerable.

Population instability, through control of reproductive success, may influence the zoogeographic distribution of nudibranchs, especially if temperature exerts an influence on population growth and stability. Lemche $(1938,1941)$ postulated that thermal reproductive limits may determine ranges of arctic and subarctic opisthobranchs, and Franz (1970) suggested that high temperatures limit reproduction and survival of boreal and boreo-subarctic species. These ideas have not been experimentally verified, however.

Successful resolution of these problems requires detailed analysis of the life cycles. Relatively few studies have contained long-term observations of nudibranch populations. Papers containing field observations of life cycles include those of MrLLER (1961, 1962), Thompson (1958, 1961a, 1961b, 1964), Swennen (1961), and Schmekel (1968). Only Potrs (1970) has successfully quantified population changes, however, using absolute census to monitor populations of the large annual species, Onchidoris fusca. Census techniques cannot be applied to the smaller subannual species, in which population surges are most pronounced, however. Hence, no quantitative data are available for these species.

This study will attempt to quantify populations of subannual species by relating nudibranch density to biomass of the prey organisms. The information obtained is used to explain population instability, its relationship to thermal sensitivity, and its effects on the ecology of the fouling community.

\section{METHODS}

\section{Study location and collection sites}

The majority of specimens used in this study were collected in the Mystic River, Noank, Connecticut (USA), from the locations shown in Figure 1. These sites are: (1) Outer perimeter of Beebe Cove along the side of the railroad trestle; depth, low subtidal to $2 \mathrm{~m}$; bottom, primarily eelgrass, mud, and small rocks; (2) Inside southern half of Beebe Cove; depth, 0.5 to $1.5 \mathrm{~m}$; bottom, eelgrass and mud; (3) Shore between the Marine Research Laboratory of the University of Connecticut, and the Noank Town Beach; depth, low intertidal to $3 \mathrm{~m}$; bottom, sand, mud, and shell, with some eelgrass and extensive Codium; (4) Pier pilings of the Marine Research Laboratory; depth, 0.5-2 m; (5) South side of the small cove between Ram Island and the South Quirk; depth, low intertidal to $3 \mathrm{~m}$; bottom, rock, eelgrass, sand, and abundant fucoid algae; (6) Hull of wooden ship, aground on the north-west side of the North Quirk, 
extending into depths of $2.5 \mathrm{~m}$; the wood of the hull is partly riddled with Teredo, but firm wood is covered with a luxuriant growth of Laminaria, Tubularia, and other fouling organisms; (7) Eelgrass beds, Noank Harbor; depths, 1-5 m; bottom, muck, eelgrass, and Laminaria.

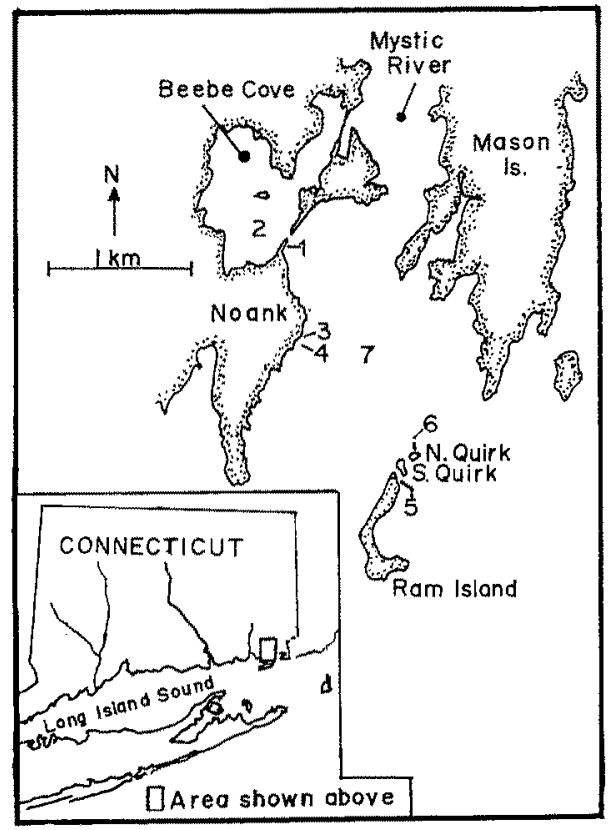

Fig. 1: Map of the lower Mystic River, showing collection sites (see text)

Other sites where collections were made include the Barn Island marsh at Stonington, Connecticut; Point Breeze Landing in the Thames River at Montville, Connecticut; and tidepools at the Marine Sciences Institute of Northeastern University, Nahant, Massachusetts. Tropical species (Tridachia crispata and Facelina sp.) were collected by Robert Wharton at Harry Harris Park in the Florida Keys.

\section{Sample collection and treatment}

All quantitative samples were collected utilizing SCUBA. Samples of the nudibranchs, together with their food species, were collected in mesh bags underwater, placed in buckets, and returned immediately to the laboratory for separation, counting, and measurement. In the separation process, clumps of the hydroid or algal food species were carefully teased apart under a dissection microscope. As nudibranchs and egg masses were located, they were immediately transferred to fingerbowls of seawater. Each clump of material was examined several times at different magnifications to ensure thorough separation. The nudibranchs, except Tergipes tergipes, were then 
carefully relaxed by stepwise addition of either $10 \%$ magnesium chloride or $1 \%$ succinylcholine $\mathrm{HCl}$. After complete relaxation, each slug was measured and the egg masses were counted. The algal or hydroid material was then picked clean of contaminants, washed once in tapwater, dried overnight at $110^{\circ} \mathrm{C}$, and weighed on a Mettler semimicro balance. Tergipes, because of their small size and slow movement, were measured crawling and unrelaxed.

Length measurements given in this paper refer to the distance between the anterior margin of the head or notum, excluding the tentacles, and the posterior tip of the tail. These correspond to the standard lengths "Ac" (aeolids) and " $A$ " (dorids) of RissoDominguez (1963). Egg diameters were obtained from freshly-laid, uncleaved eggs, which were placed on glass slides with a coverslip floated on sufficient seawater to prevent flattening of the yolk.

Relaxed slugs often take several days to fully recover from the effects of relaxation. For this reason, the nudibranchs, once relaxed, were either destroyed or used for dry-weight determinations, but were not used for any other experiments.

Slugs used for other purposes were collected intertidally or underwater, using the suction collector described by CIARK (1971). The strong suction effect produced by this device is particularly well-suited for collection of nudibranchs which often cling tightly to the substrate and may be injured by the use of forceps. The use of this device assured optimum physiological condition of those specimens which were to be used for subsequent experiments and observations.

To determine dry weights of the animals used in population measurements, lengths were measured initially, and these were later converted into equivalent dry weight. To calculate the ratio of the dry weight of nudibranchs in the sample to the dry weight of the food species, a regression analysis of the relationship of the log length and log dry weight was performed using the method of least squares. The regression equations are summarized in Table 1 . The total dry weight of a sample was determined by summing the calculated dry weights according to the formula:

$$
\text { Sample dry weight }\left(x 10^{-5} \mathrm{~g}\right)=\sum_{i=1}^{\mathrm{n}} 10(\log i)
$$

where $\log \mathrm{W}_{\mathrm{i}}=m \log L_{i}+b$, and where $\mathrm{n}=$ number of nudibranchs in sample; $\log W_{i}=\log$ dry weight of $i$ th nudibranch; $m=$ regression slope; $\log L_{i}=\log$ of length in mm of $i$ th nudibranch, and $b=$ intercept of regression line.

\section{Food preferences}

The food species of the nudibranchs studied were determined according to two of the criteria of Swennen (1961): constant association of the nudibranch and its suspected food organism in the field, and actual ingestion of the suspected food species during laboratory observation. 


\section{Measurement of thermal tolerance}

Respiration rates of the nudibranchs in this study were determined by use of a Gilson differential respirometer. Slugs were maintained twenty-four hours at the temperature of the collection site in filtered seawater taken from the collection site. Three $\mathrm{ml}$ of Millipore-filtered seawater and one or more slugs, depending on size and availability of the species used, were placed in each respirometer flask ( $7 \mathrm{ml})$. A salinity of $30 \%$ was used for all Noank specimens, and $34 \%$ for Nahant specimens. $0.2 \mathrm{ml}$ of $20 \% \mathrm{KOH}$ were placed in the well of the flask to absorb $\mathrm{CO}_{2}$. Flasks were agitated at the minimum rate available, 78 shakes per minute. Agitation was used to enhance equilibration of the flasks; however, significantly faster rates of agitation damaged the animals by knocking off papillae, and so were not used. All volume changes were compensated using a blank flask and were corrected to standard temperature-pressure.

Table 1

Regression equations relating length and $\mathrm{dry}$ weight $\left(\log _{10} W=M \log _{10} L+b\right.$, where $W$ is weight $\times 10^{-5} \mathrm{~g}, L$ is length in $\mathrm{mm}$, and $\mathrm{r}=$ coefficient of correlation)

\begin{tabular}{|lccc|}
\hline \multicolumn{1}{c}{ Species } & $m$ & $b$ & $r$ \\
\hline Ancula gibbosa & 1.8862 & 0.8386 & .97 \\
Alderia modesta & 2.0030 & 0.5874 & .84 \\
Catriona aurantia & 1.7877 & 1.1615 & .93 \\
Cratena pilata & 2.3899 & 0.2958 & .95 \\
Elysia catulus & 1.4655 & 0.9859 & .90 \\
Eubranchus exiguus & 2.5560 & 0.1443 & .93 \\
Hermaea dendriticat & 2.6598 & 0.6255 & .98 \\
Polycera dubia & 3.1214 & 1.0259 & .99 \\
Polycerella emertoni & 1.4567 & 0.6988 & .86 \\
Stiliger fuscatus & 2.0461 & 0.5280 & .94 \\
Tenellia fuscata & 2.4099 & 0.2501 & .95 \\
Tergipes tergipes & 1.7634 & -0.0226 & .85 \\
\hline
\end{tabular}

The limitation of numbers of specimens available necessitated the use of the same animals for the entire range of temperatures at which respiratory rates were measured. In carrying out a respiratory run, an initial temperature was selected several degrees below the ambient temperature. Temperatures were then raised in increments of five degrees, concluding the experiment when the animals became morbid or showed signs of imminent death (mucus release, cessation of movement). Typically, a range of five or six temperatures was used. The entire experiment usually required about twentyfour hours, with an average exposure at each temperature of about three hours. An equilibration interval of one-half hour minimum was used before readings were begun at a new temperature.

This procedure, although a compromise in several respects, was judged to measure thermal tolerances and limits at least qualitatively, and to provide some measure of adaptation to changing temperatures. To measure longterm thermal adaptation, the series was repeated seasonally when possible; however, the rapid population decrease of most species seasonally made this difficult except for a few species. 
The temperature record (Fig. 2) was derived from the water temperature recorder at the Marine Research Laboratory. Additional surface temperatures were measured at collection sites at the time of sampling using a stem thermometer.

\section{RESULTS}

\section{Annual temperature cycle}

The annual temperature cycle of the Mystic River estuary (Fig. 2) shows a large and rapid variation of temperature, reflecting a continental marine climate. The annual variation of about $26^{\circ} \mathrm{C}$ is even higher than that cited by SANDERs (1969) for Buzzards Bay, Massachusetts. Even more extreme temperatures may be observed at one

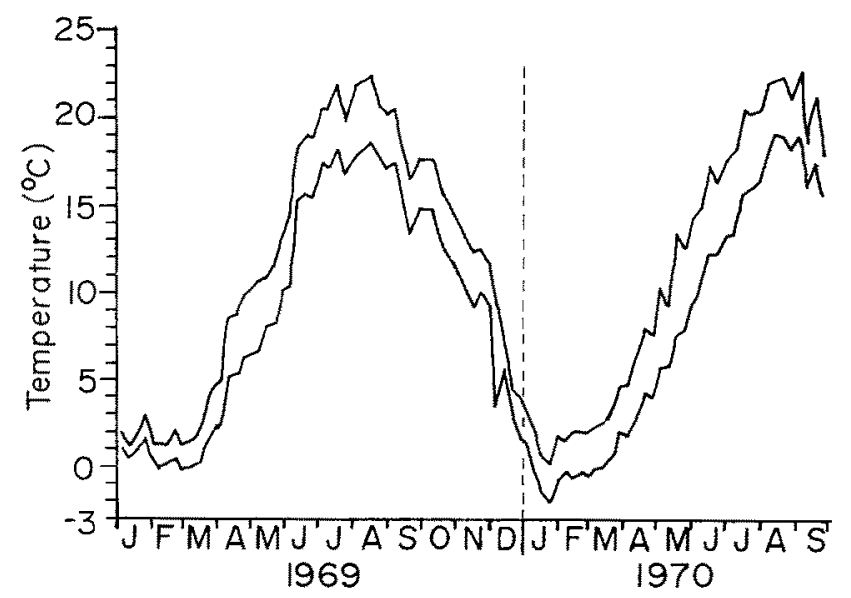

Fig. 2: Mean weekly water temperatures at Noank, Connecticut at surface (lower line) and $-2.0 \mathrm{~m}$ (upper line)

of the sampling sites, Beebe Cove, where summer maxima may exceed $27^{\circ} \mathrm{C}$, and ice forms at the surface in winter. Water temperatures at Ram Island sites ( 5 and 6 ) are somewhat more moderate than those recorded at Noank.

The second year of the study period was notably cooler than the first year (1969). The first quarter of 1969 was warmer, by an average of $1.75^{\circ} \mathrm{C}$, than the first quarter of 1970 , and the maximum summer temperature was reached two weeks later in 1970 than in 1969. Temperature changes were most rapid during the months of April through June, with a rate of warming of about $6^{\circ} \mathrm{C}$ per month, and from September through January, with a rate of cooling of about $4^{\circ} \mathrm{C}$ per month. Temperature varies little in February and March and in July and August, with less than $2^{\circ} \mathrm{C}$ change per month. 


\section{Food preference}

Table 2 presents a nearly complete list of food species. Question marks denote constant association of the nudibranch and the suspected food species in the field, but ladk of laboratory verification of feeding.

Table 2

Food species of Nudibranchia and Sacoglossa at Noank, Connecticut

\begin{tabular}{|c|c|}
\hline Species & Foodspecies \\
\hline & \\
\hline $\begin{array}{l}\text { Aeolidia papillosa } \\
\text { Alderia modesta }\end{array}$ & $\begin{array}{l}\text { Metridum dianthus } \\
\text { Vaucheria }\end{array}$ \\
\hline Ancula gibbosa & Bowerbankia gracilis \\
\hline Catriona aurantia & Tubularia laryn $x, T$. crocea \\
\hline Corypbella sp. & Tubularia sp.? \\
\hline Cratena pilata & Tubularia crocea, Obelia geniculata, Tubularia larynx \\
\hline Cutbona concinna & Sertularia pumila? \\
\hline Dendronotws frondosus & Tubularia crocea, Obelia (2 spp.) \\
\hline Doridella obscura & Bryozoa? \\
\hline Doris verrucosa & Halicbondria bowerbanki \\
\hline Doto coronata & Thuiarea argentea, Sertularia pumila \\
\hline Elysia catulus & Zostera marina \\
\hline Elysia chlorotica & Cladophora sp., Vaucheria \\
\hline Eubranchus exiguus & Obelia ( 2 spp.) \\
\hline Facelina bostoniensis & Tubularia larynx \\
\hline Hermaea dendritica & Codium fragile tomentosoides \\
\hline Onchidoris aspera & Parasmittina nitida \\
\hline Onchidoris fusca & Balanus \\
\hline Polycera dubia & Cryptosula pallasiana? \\
\hline Polycerella emertoni & Bowerbankia gracilis \\
\hline Stiliger fuscatus & Chatomorpha lineata, Cladophora gracilis \\
\hline Tenellia fuscata & $\begin{array}{l}\text { Obelia (at least three spp.), Cordylophora lacustris, } \\
\text { Ectopleura dumortieri, Bougainvillea carolinensis, } \\
\text { Tubularia crocea }\end{array}$ \\
\hline Tergipes tergipes & $\begin{array}{l}\text { Tubularia croced } \\
\text { Obelia geniculata }\end{array}$ \\
\hline
\end{tabular}

\section{Seasonal occurrence}

Figure 3 summarizes seasonal occurrences of southern New England species, based on averaged data from four years of collection at Noank. Due to the wide seasonal variation of numbers of some species, these data must of necessity include some estimation and extrapolation from other information obtained in this study.

\section{Egg sizes and development types}

Length of the larval stage is an important feature of nudibranch life cycles, as this determines dispersal distance and ability to exploit new food species. Dimensions given are mean diameters of uncleaved eggs, plus or minus one standard deviation. The 
figures are derived from measurement of a minimum of ten eggs for each species. The development types are determined according to THompson (1967). Type 1 includes small ova, $40-170 \mu \mathrm{m}$ in diameter, which have a relatively short hatching time (2-28 days) and a long (but undetermined) planktonic swimming phase. Type 2 includes larger ova, $110-250 \mu \mathrm{m}$ in diameter, a longer embryonic period (4-42 days), and veligers which swim for only a few days or may settle and metamorphose immediately upon hatching.

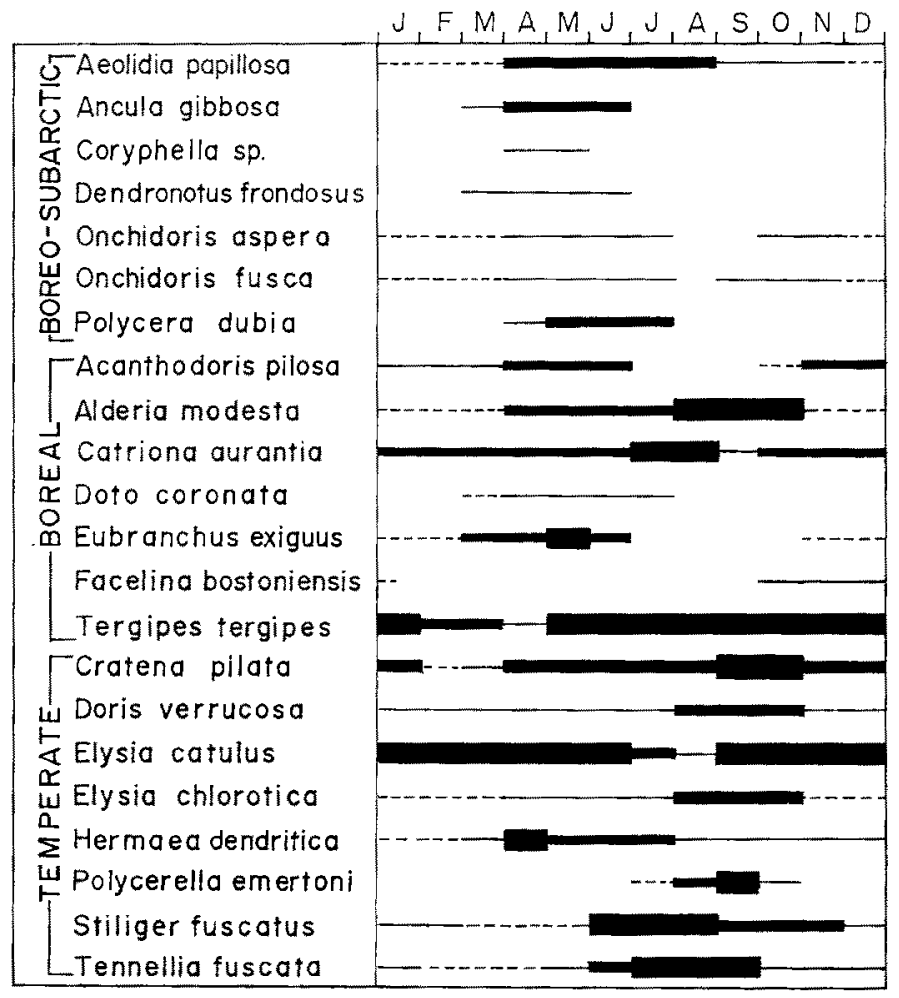

Fig. 3: Seasonal abundance of Nudibranchia and Sacoglossa at Noank, Connecticut. Thick lines indicate more than 50 animals collected per hour of collecting time; medium lines, $5-50 / \mathrm{h}$; thin lines, less than $5 / \mathrm{h}$; broken lines, presence inferred but probably in too small numbers to successfully collect. Absence of line indicates species not present

\section{Life histories of Noank nudibranchs}

The descriptions of life histories presented here are the results of observations over a four year period. In some cases, populations occurring at Noank are too small to allow successful quantitative sampling. In other cases the quantification technique used was not applicable because of the species' free-ranging habits (e. g. large dorids). Where quantitative sampling was not possible, data are based on observations over a minimum period of two years. 
Table 3

Egg diameters of Nudibranchia and Sacoglossa occurring at Noank, Connecticut (mean uncleaved yolk diameters, \pm standard deviation)

\begin{tabular}{|crc|}
\hline Species & Size & Development \\
\hline Nudibranchia & & \\
Doridacea & $74.0 \pm 1.7 \mu \mathrm{m}$ & Type 1 \\
Ancula gibbosa & $80.9 \pm 3.4$ & 1 \\
Acanthodoris pilosa & $57.8 \pm 1.1$ & 1 \\
Polycerella emertoni & $93.7 \pm 4.4$ & 1 \\
Doris verrucosa & $76.4 \pm 2.5$ & 1 \\
Polycera dubia & $82.3 \pm 3.2$ & 1 \\
Aeolidacea & $149.1 \pm 4.7$ & 2 \\
Aeolidia papillosa & $80.0 \pm 3.0$ & 1 \\
Catriona aurantia & $183.5 \pm 3.9$ & 2 \\
Eubranchusexiguns & $79.4 \pm 4.8$ & 1 \\
Tenellia fuscata & $74.8 \pm 3.5$ & 1 \\
Tergipes tergipes & $113.4 \pm 7.0$ & 1 \\
Cratena pilata & $89.5 \pm 5.5$ & 1 \\
Dendronotacea & & \\
Dendronotus frondosus & $75.3 \pm 3.1$ & 1 \\
Doto coronata & $72.0 \pm 5.1$ & 1 \\
S a co glos s a & $64.5 \pm 2.0$ & 1 \\
Elysia catulus & N.D. & \\
Hermaea dendritica & & \\
Stiliger fuscatus & & \\
Alderia modesta & & \\
\hline
\end{tabular}

In the following discussion, the term "annual species" is used in the sense of MILLER (1962) to mean one generation produced annually, with the larvae settling during a restricted interval of a few weeks. "Sub-annual" refers to species having two or more overlapping generations each year.

In determining whether a population was likely to be self-sustaining, with sufficient larvae produced each year to propagate succeeding generations at that location, the following criteria were used: length of appearance of adults, number of eggs produced, thermal tolerance, and the depth range of the adults. Adults present for only a few months, or not successfully producing eggs, and confined to high subtidal areas, or those which died from rising spring temperatures, were considered unlikely to resupply juveniles to an area. These are reasonable assumptions if one accepts an. estimate of the length of the veliger stage of two months or less.

Zoogeographic remarks relating to the species discussed below follow FRANZ (1970) unless otherwise noted.

\section{Acanthodoris pilosa (MüLLER)}

Distribution: boreal amphiatlantic, south to Virginia. At Noank, it may be collected from sites 1, 3, 4, and 5. Animals may occur in the middle of the Fucus zone feeding on Flustrellidra, or feeding on Cryptosula on the undersides of rocks in the high sub-tidal region. The smallest individuals $(5 \mathrm{~mm}$ ) were observed in November, 
and the adults usually disappear in early June. Egg masses may be collected sporadically from December through June. This species probably does not have a sustained population, and recruitment is probably from more northerly localities. One generation per year is probable, with post-larval lifespan probably about $8-9$ months.

\section{Aeolidia papillosa (Linnaeus)}

Distribution: Boreo-subarctic, amphiatlantic, south to Maryland. Collected at Noank at sites 5 and 6, subtidally in association with Metridium, occasionally in the low intertidal zone. Smallest individuals $(5 \mathrm{~mm})$ were taken in early April from lobster pot scrapings. One generation occurs per year, though some adults may live up to two years. Spawn was collected April through July.

\section{Alderia modesta LovÉN}

Distribution: Discontinuous boreal amphiatlantic. This species was collected at Noank at site 2, but larger populations occur at Barn Island on Vaucheria patches on the high intertidal Spartina marsh. Alderia seems to favor low salinities, as the largest individuals and densest populations encountered were from Steamboat Landing, Cheesequake, New Jersey, where the salinity averages 10\%. Likewise, the largest populations at Barn Island were in regions with some fresh water dilution. The adults overwinter there in salt ponds and bays as reported by Bleakney and Bailey (1967). Major breeding populations appear on the Vaucheria patches from May through October. Probable life span in southern New England is from two to six months.

\section{Ancula gibbosa (Rrsso)}

Distribution: Boreo-subarctic amphiatlantic with southern limit in Connecticut. This species was collected at sites 1, 3,5, and 6, under rocks, feeding on Bowerbankia. The smallest individuals $(2-3 \mathrm{~mm})$ are taken in early March, and the largest $(20 \mathrm{~mm})$ in late June, just prior to the disappearance of the adults. Egg masses are present from April through June. One generation occurs annually. The life span is about four months at Noank, but the population is probably not self-sustaining, and all individuals found in Connecticut probably originate from eggs produced by more northerly populations.

\section{Catriona aurantia (ALDER \& HANCOCK)}

Distribution: Boreal amphiatlantic, south to New Jersey. Collected at sites 4, 6, and 7, wherever Tubularia occurs. The individual slugs are found clustered together at the base of the colony of Tubularia, and do not emerge from this position. The "nest" area is delineated by a zone of silt and fecal material in which the adults and 
their egg masses may be found. The reniform egg-masses, containing 200-1000 eggs, are loosely attached to the basal stolons of the Tubularia colony. The larvae appear to have type 2 development, but I have been unable to induce metamorphosis in the presence of Tubularia polyps.

The growth of Tubularia fluctuates seasonally. From May through late July, $T$. crocea is the dominant species, with peak growth in June. From November through April T. larynx dominates, with peak growth in March and April. During April a
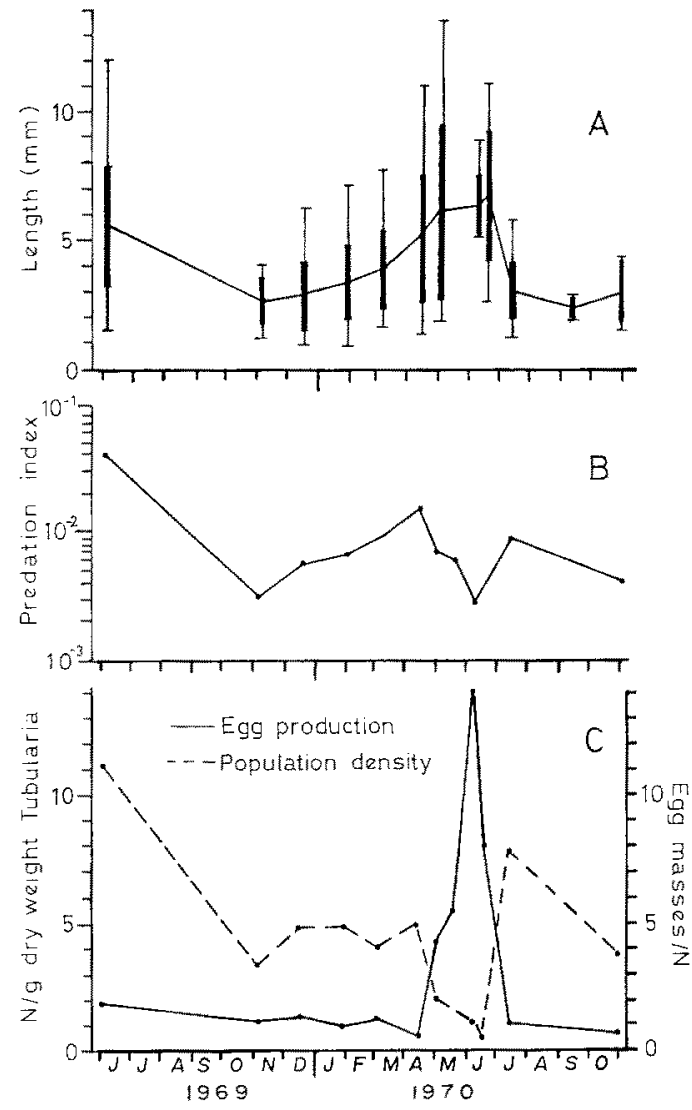

Fig. 4: Annual cycle of Catriona aurantia. (A) Range, mean, and standard deviation of lengths. (B) Predation index (ratio of Catriona dry weight to hydroid dry weight). (C) Egg production rate and population density

mixture of the two species growing together can be found. During the summer, $T$. crocea grows in small clumps attached to Zostera and Laminaria as well as on rocks and wood. These small clumps attract few Catriona, but are readily colonized by Cratena pilata. In mid-summer, the Tubularia growth sloughs away, with large clumps, apparently dead, remaining attached by a few basal stolons for several days. Very little new growth is visible until late October or early November. During this interval, however, Teredo-infested wood can be pried from the ship hull, and small Tubularia polyps are 
visible interwoven with the Teredo tubes. Small Catriona, averaging about $2.5 \mathrm{~mm}$, can be detected feeding on this network of Tubularia together with small egg masses.

As shown in Figure 4a, the smallest individuals are present throughout the year, suggesting continuous recruitment of a small number of larvae all year. Gradual increase in mean and maximum size occurs from August through June. As egg production begins at a small size and continues all year, this low rate of growth may be a result of a major portion of energy input being transferred into egg production. Indeed, total weight of eggs in the 30 April and 19 May samples equalled $63 \%$ and $95 \%$ of the total weight of nudibranchs in the samples, indicating a quite considerable output. Figure $4 \mathrm{c}$ shows a peak in egg production in early June, coinciding with a "crash" in population size and nearly coinciding with maximum mean size. Paralleling the peak in egg production and lagging by about six weeks, the population size shows a sharp increase.

Figure $4 \mathrm{~b}$ presents a predation index, which is here defined as the ratio of nudibranch biomass to food species biomass. Three peaks are shown; two, in June of 1969 and 1970, immediately precede the period of sloughing of the hydroid; the third, in April, 1970, coincides with the change from $T$. larynx to $T$. crocea as the dominant species. This suggests that when the predation index reaches a critical level, on the order of $1 \%$, the hydroid habitat incurs damage from overfeeding. In one case, this may enable $T$. crocea to gain an initial foothold on a surface previously covered by T. larynx. This seems probable if related to Catriona's habit of concentrating all activities, including feeding, at the base of the hydroid colony. Penetration of tunnelled wood may be an important feature for survival of $T$. crocea colonies during peak predation periods, permitting rapid regrowth of colonies after feeding activity decreases.

\section{Cratena pilata (GoulD)}

Distribution: Endemic west Atlantic, extending south to Brazil (Marcus, 1972). Cratena was collected at sites 2, 4, 5, 6, and 7, from Tubularia and Obelist. Although tufts of Tubularia on eelgrass are colonized as early as April, Cratena does not become common in colonies on the ship hull (site 6) until September.

As Cratena and Catriona aurantia both feed on Tubularia, these species may compete with each other. Competition is decreased, however, by differences in behavior and seasonal occurrence. Cratena feeds on all portions of the Tubularia colony, but prefers to feed on the hydranths, while Catriona feeds on the basal stolons. Major activity of Cratena is in the autumn, while Catriona individuals are small and population density is at a minimum. This temporal separation of species is shown by Figure 5, which presents the relative abundance of four species of nudibranchs in quantitative Tubularia samples. Cratena populations first appear in the quantitative samples in April, and reach a peak in October, with some Cratena present at least through January. Egg production is apparently limited to the period of May through November, when water temperature is above $10^{\circ} \mathrm{C}$. No eggs were found associated with Cratena of less than $5 \mathrm{~mm}$, suggesting that this may be the minimum size for egg production. 


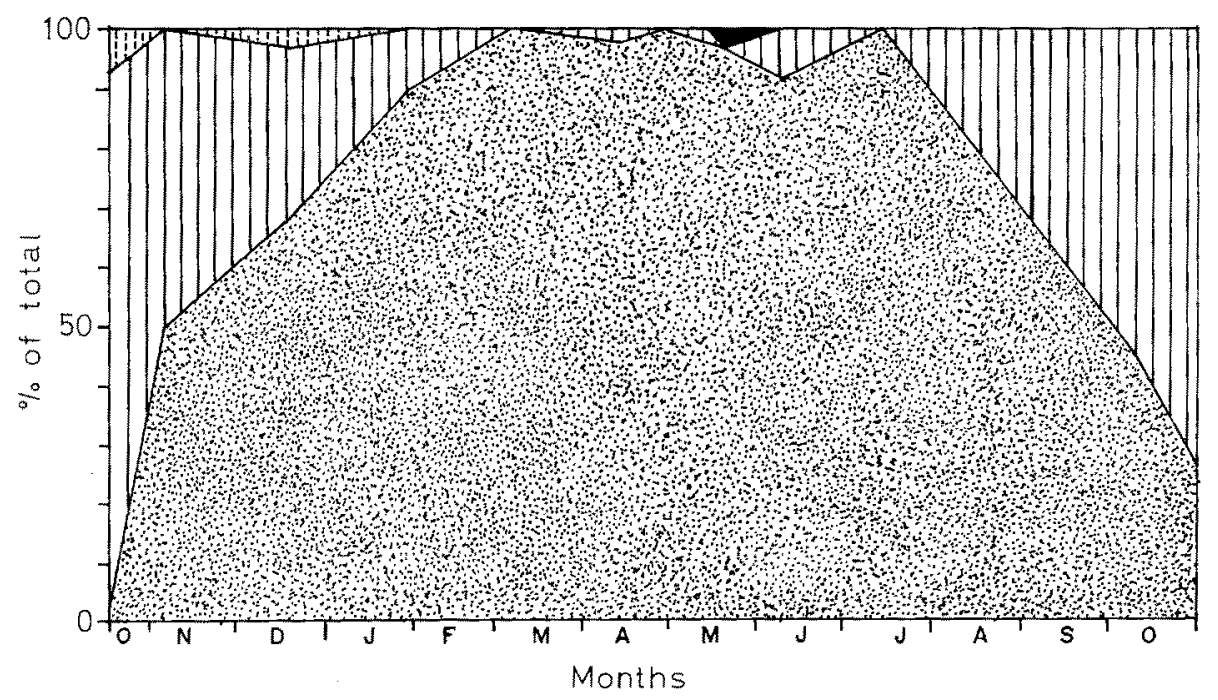

Fig. 5: Competetive interaction of four nudibranchs feeding on Tubularia. Stippled area indicates Catriona aurantia; solid vertical lines, Cratena pilata; broken vertical lines Dendronotus frondosus; black area, Facelina bostoniensis

Cratena appears to actively compete with Tergipes tergipes for the hydroid Obelia geniculata. On Laminaria fronds, Tergipes populations are already well established when Cratena larvae begin to settle. Cratena may be found in this habitat for only a relatively short period, and never becomes the dominant species on Laminaria thalli. On Zostera leaves, however, a transient growth of O. geniculata appears in September and October. In a single quantitative sample from eelgrass colonized by Obelia (site 5, 10-12-70), Cratena composed $98 \%$ of the sample, as compared with $2 \%$ for Tergipes. The PI for Cratena in this sample equalled $6 \%$, and possibly due to overcrowding, the mean size of the slugs was small, only $2.1 \mathrm{~mm}$. Overfeeding was evident, with much hydroid damage, and no egg masses were present in the sample, although a few egg masses were found on other Zostera leaves. This suggests that reproductive success on transient Obelia growths from Zostera is lower than on the relatively stable Tubularia. The smaller population densities of Cratena on Tergipesdominated Obelia, and the failure of Cratena to occupy Tubularia colonies until fall if Catriona is present, suggests that larvae may be able to discriminate against preoccupied substrates as a mechanism reducing competition.

Based on the population decline from December to March, Cratena probably has a maximum lifespan of less than six months, with several generations produced from April through November.

\section{Dendronotus frondosus (AscANIUs)}

Distribution: Circumpolar, south to New Jersey. The smallest individuals of Dendronotus (2-3 mm) were collected in March and April. This species is never very 
common at Noank, but may be collected on both Tubularia and Obelia (sites 4, 5, and 6). The adults apparently die in June after spawning, and maximum size attained here is about $35 \mathrm{~mm}$. This species probably lives a maximum of three months in littoral habitats at Noank, although larger specimens, over $50 \mathrm{~mm}$ in length, occur in deeper water $(25 \mathrm{~m})$ in Long Island Sound, and presumably live at least a full year.

\section{Doris verrucosa Linnaeus}

Distribution: Amphiatlantic, north to Cape Cod (FRANZ, 1970). This species occurs on the muddy bottom of Beebe Cove (site 2), and apparently has an annual or biannual cycle. Egg-masses are produced in July, August, and September. The large adults apparently die off in September and October, leaving smaller individuals (ca. $20 \mathrm{~mm}$ ) which overwinter in a dormant state.

\section{Doto coronata (GMELIN)}

Distribution: Amphiatlantic, south to New Jersey. This species is rare at Noank, where it occurs primarily in the high subtidal zone, and individuals are present primarily in late spring. All specimens were less than $5 \mathrm{~mm}$, suggesting that they had settled recently. I have rarely observed a few egg masses associated with these individuals, but most individuals were not found near eggs. Possibly the population density is too low to permit frequent mating.

A few specimens appear sporadically each year at stations 1,4 , and 6 . They have always been associated with thecate hydroids. The latest collection of this species was in July from dredging in Fisher's Island Sound at a depth of $20 \mathrm{~m}$. Populations in the upper sub-tidal and intertidal zones probably do not live past June and are probably not self-sustaining. It is possible, however, that deep-littoral populations of this species may annually supply larvae for shallow-water colonization.

\section{Elysia catulus (GouLD)}

Distribution: Endemic northwest Atlantic, south to Virginia. The true southern limit of this species may possibly extend to North Carolina, but verification of this will probably depend on re-establishment of Zostera marina, which in North Carolina has not fully recovered from the eelgrass blight. This species is undoubtedly the commonest sacoglossan in Connecticut waters, occurring virtually wherever Zostera grows. This species feeds directly on Zostera, and this is the first report of a sacoglossan which feeds on a spermatophyte plant. Feeding is in the typical sacoglossan manner; the cell wall is punctured by the radular tooth and the cell sap is withdrawn by suction. The empty cells are readily visible as darker areas on the leaf surface. This method of feeding may have considerable importance; penetration of the leaf cuticle could serve to introduce disease organisms into a leaf which is otherwise rather impervious, and 
suggests that Elysia catulus might have been a vector in the transmission of the Zostera wasting disease of 1931-1932 (HopkrNs, 1957; RENN, 1936). The act of feeding in itself causes negligible damage, due to low densities of Elysia.

$E$. catulus is a true annual species with a restricted period of egg production. Settlement of the larvae occurs in late August and early September, and slow, continuous growth occurs until June (Fig. 6), when egg production begins. Mean length decreases throughout the period of egg production, apparently as a result of tissue resorption (to provide gamete material). The spiral egg masses, containing up to 1000 eggs, are usually attached to the distal third of the eelgrass leaf. All adults disappear in late July, following the period of egg production. Smallest individuals were often

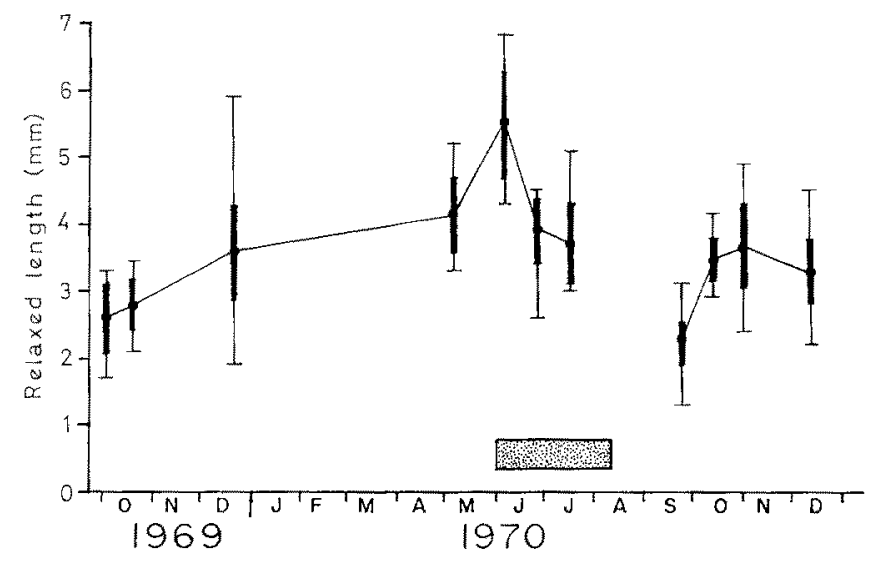

Fig. 6: Annual cycle of Elysia catulus. Range, mean, and standard deviation of lengths are shown; stippled area indicates period of egg production

overlooked in the earliest samples, but were later found to occur secreted under the inrolled leaf-margin. As size increases, the animals crawl out onto the exposed flat parts of the leaves. As the temperature falls, adults seek the crevice within the fascicle binding adjacent leaves, and may be found in clusters of up to ten individuals. This mechanism enhances survival during winter months when the old Zostera leaves die and break loose, since the Elysia are sheltered within the young leaves which form the following summer's growth. Survival of juveniles and adults through the winter is apparently high. The rate of collection declined continuously from 185 animals per hour in September to 85 animals per hour in July, indicating fairly constant mortality from the time of metamorphosis until spawning.

\section{Elysia chlorotica Gould}

Distribution: Endemic to northwest Atlantic, south to Virginia. This species is not common at Noank, and appears to prefer the lower salinity marshes where Alderia modesta occurs. The largest specimens occur in late summer and early autumn, while 
somewhat smaller specimens may be collected in the spring. This suggests that this is an annual species with reproduction in late autumn.

\section{Eubranchus exiguus (Alder \& Hancock)}

Distribution: Boreal amphiatlantic, south to New Jersey (Loveland et al., 1969). This species occurs on Obelia, chiefly associated with Zostera leaves. The first specimens, appearing in March, are quite small, length 1.5 to $3 \mathrm{~mm}$, and grow to a maximum length of $10 \mathrm{~mm}$ by mid-April. Eggs are produced by individuals $3 \mathrm{~mm}$ in length. In a single quantitative sample (Barn Island, 6-8-70) taken about two weeks before the disappearance of this species, Eubranchus reached a density of 14 animals per gram of Obelia, with a predation index of $1.3 \%$. Egg mass weight equalled $40 \%$ of the dry weight of the nudibranchs in the sample. Eubranchus does not occur at Noank in the autumn, even though a regrowth of Obelia occurs on the Zostera then. Eubranchus apparently does not have a self-sustaining population at Noank, and appears to be a sub-annual species.

\section{Facelina bostoniensis Couthoux}

Distribution: Boreal, endemic western Atlantic; south to Connecticut (personal observation). The very brief occurrence of this species at Noank suggest that Noank probably represents the extreme southern range of $F$. bostoniensis. No egg masses were observed in field collections, and this species probably does not reproduce in Connecticut waters.

\section{Hermaea dendritica (ALDER \& $\mathrm{H}_{\text {ANCOCK}}$ )}

Distribution: This species occurs on both sides of the Atlantic and Pacific oceans. Its occurrence in the northwestern Atlantic is apparently recent (CLARK \& FRANZ, 1969). This species was also reported from Curacao and North Carolina (Marcus \& Marcus, 1970), and I collected specimens in the Florida Keys (April, 1973). At Noank, this species was collected from sites 1, 3, 5, and 6, solely from the alga Codium.

Quantitative data for this species are presented in Figure 7. Egg production begins in early April, at a temperature of approximately $5^{\circ} \mathrm{C}$. Egg production reaches a peak in early June, at a temperature of approximately $15^{\circ} \mathrm{C}$, and rapidly declines thereafter. Egg production continues at a low rate all summer and into the autumn, and some egg masses are present as late as October. Maximum recruitment occurs in the colder months of late winter and spring, as water temperature increases from $0^{\circ}$ to about $15^{\circ} \mathrm{C}$, with the peak population density reached in early June. Recruitment apparently continues at a slow rate during the rest of the year, but is apparently outweighed by mortality. As a result, population size declines continually after the June peak.

Maximum size is reached in the coldest months, before egg production begins. The 
mean length drops significantly as the first juveniles settle and rises again as recruitment decreases. The rate of this rise and the sudden appearance of large adults in March both indicate rapid growth of individuals.
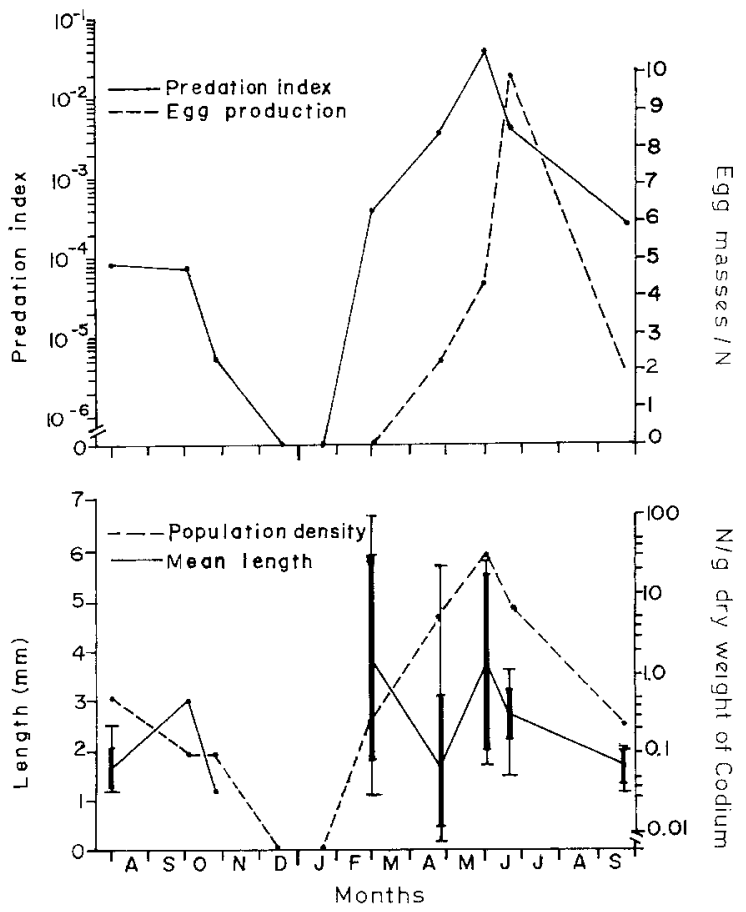

Fig. 7: Annual cycle of Hermaea dendritica. Upper: Predation index (ratio of sample dry weight to algal dry weight) and egg production rate. Lower: Population density and growth curve, with mean length indicated by solid circles, standard deviation by heavy vertical lines, and range by thin vertical lines

Significant damage to the Codium is visible at the time of the maximum population density. During the months of May and June, the Codium thalli show weakened spots at the branch points, where feeding by Hermaea has collapsed the utricles of the alga. The damage is enhanced by the habit of Hermaea of clustering together at these branch points in groups of up to 50 individuals, thus concentrating feeding activity in small areas. It appears from the life-cycle data that the northern populations of Hermaea dendritica are adapted to a fairly narrow range of cool temperatures, such as those in its European and eastern Pacific ranges. In those ranges the species probably reproduces all year with several overlapping generations each year. It seems highly significant that the only west Atlantic distributional record south of Connecticut occurred in March, during the coldest part of the year (Marcus, 1961a). An examination of Marcus' collection site in July and August 1970 failed to locate Hermaea even though Codium was present (personal observation). Marcus' records from Curacao (1970) occur still earlier, in January and February. If these occurrences represent population peaks, then a seasonal movement of populations northward occurs as vernal temperatures increase, via larval dispersion. 


\section{Onchidoris aspera (ALDER \& HANCOCK)}

Distribution: Amphiatlantic boreal-subarctic, south to Connecticut. This species occurs marginally at Noank during the cooler months of the year. It has been collected at sites 3,5 , and 7 . It appears to be a true annual species with a reproductive period confined to late spring. The adults appear to die off in early summer, but collection of small individuals in late July on deepwater $(30 \mathrm{~m})$ lobster pots suggests that this species may survive all year in sublittoral habitats, and that recruitment of supralittoral populations may be from eggs produced by sublittoral populations.

\section{Onchidoris bilamellata (MULLER)}

Distribution: Amphiatlantic boreal subarctic, south to Connecticut. This species occurs marginally at Noank, and has been collected only at site 5. It occurs only during the cooler months. The species is probably a true annual with a reproductive period in the spring, but Noank populations are probably not self-sustaining.

\section{Polycera dubia (SARs)}

Distribution: Amphiatlantic boreo-subarctic, south to Connecticut. This species was collected at Noank at sites 1,3, and 5. Polycera occurs in nearly the same habitat as Ancula, but seems to be more mobile, and can occasionally be taken crawling on the upper surface of rocks rather than only on the underside. Polycera survives slightly longer than Ancula, and may be collected until late June. Like Ancula, this species probably settles in March, and grows to sexual maturity by April. The adults apparently die off in June and the population is not self-sustaining. Since this is primarily a supra-littoral species, it is unlikely that recruitment is from a local deep-water population, but rather comes from more northerly intertidal populations.

\section{Polycerella emertoni (VERRILL)}

Distribution: Warm-temperate, with northern limit at Woods Hole, possibly occurring in the Mediterranean (FRANz \& CLARK, 1972). This species has been collected at sites 1, 2, 4, 5, and 6. The first specimens appear in August, although the food species, Bowerbankia gracilis, is present for most of the year on the undersides of rocks. The adults gradually disappear during September, and egg masses may be collected through October. Egg masses are produced at a very small size ( $3 \mathrm{~mm}$ relaxed length), and contain up to 150 eggs/mass. In a single quantitative sample (August 28), slightly less than one egg mass per individual was found, with a mean size of $1.7 \mathrm{~mm}$. The predation index of this sample equalled $1.8 \%$, and overfeeding was obvious. In later samples, after the adults had disappeared, the exoskeleton of the Bowerbankia remained attached to the ship hull, but no live zooids remained. This appears to be a 
sub-annual species with overlapping generations, but the populations at Noank are probably not self-sustaining.

\section{Stiliger fuscatus (GouLd)}

Distribution: Endemic northwest Atlantic, New Hampshire to Virginia. At Noank, I have collected this species from sites 1, 2, 3, and 5. Quantitative samples on Cladophora gracilis were collected at sites 1,2, and 3. Quantitative samples on Chaetomorpha lineata were collected at site 5 .

Chaetomorpha occurs all year at Noank. A "bloom" of this alga occurs in June, with extensive regrowth of the small amounts of the alga which have survived through the winter. The maximum standing crop of this alga occurs in August, shortly before large masses of the alga break loose and are carried away by currents. Some algae remain attached to the rocks, gradually decreasing in quantity until the following summer. The second food species, Cladophora gracilis, apparently prefers inshore sites not exposed to strong currents or wave action. The growth of this alga seems to be confined to the moderately cool periods of late spring and early autumn. Tufts of the alga appear sporadically during these periods, attached loosely to rocks, eelgrass, or the mud surface. In July and August these clumps break loose and are washed out of Beebe Cove. Many of the clumps of algae eventually settle in an area of site 3 where currents are minimal.

Results of the quantitative samples are summarized in Figure 8. As the quantities of algae available for sampling and the number of Stiliger present vary so widely during the year, substantial but unavoidable gaps appear in this record. The changes of the populations from the two species of algae are generally similar, but the changes occur at different times, reflecting the somewhat different water temperatures of the two habitats. The changes of the Chaetomorpha population generally lag about a month behind those of the Cladophora population, following the faster vernal warming and autumnal cooling of Beebe Cove. In both the Chatomorpha and Cladophora populations, mean size and maximum length decrease as the larvae settle on the algae and the population density increases. Recruitment slows significantly by October and mean length begins to increase. The initial decrease in mean length at this time may represent a resorption of tissue as shown in Elysia catulus. Both populations decrease gradually in density until a few weeks after the annual regrowth of the algae. Egg production begins at about the time that the population reaches peak density, and continues through November. As the egg masses are quite transparent and difficult to find, no attempt was made to quantify egg production.

Inspection of the predation index curve (Fig. 8b) shows that the summer breakup of both species of algae is immediately preceded by a peak in both populations in which the combined dry weight of the animals approaches one percent of the algal weight. If Chaetomorpha is examined at this time, damage induced by overfeeding is quite evident. Short portions of the filaments are evacuated by withdrawal of cell-sap by the slug; the filament is thus structurally weakened. Significantly, fracture of the flament occurs at points where feeding has occurred, and feeding activity during peak 

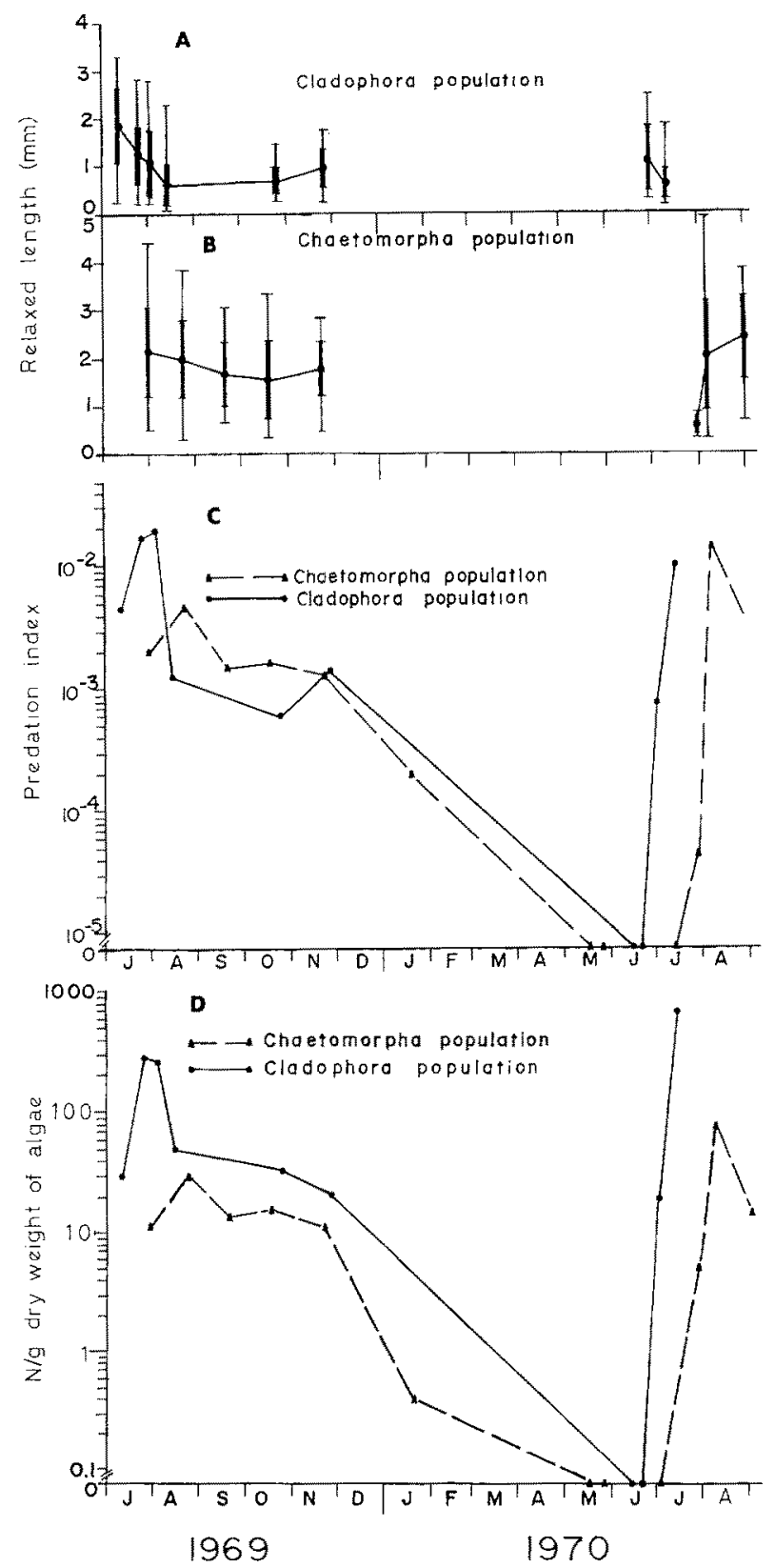

Fig. 8: Annual cycle of two populations of Stiliger fuscatus. (A) Growth curve, with mean length indicated by solid circles, standard deviation by heavy vertical lines, and range by thin vertical lines. (B) Predation index 
populations is sufficiently damaging to cause entire clumps of algae to break loose in water currents. Masses of the alga can be found drifting in the river during August each year.

The sudden rise in population density in the summer suggests that the larvae are allochthonous in origin, and that settling is probably controlled by temperature. Nevertheless, it is likely that some adults do survive the winter, and that these adults produce some of the larvae which contribute to the summer population spike.

Many pediveligers were collected during the peak recruitment period. The pediveligers settle and metamorphose at lengths between 0.20 and $0.35 \mathrm{~mm}$, and have two cerata at the time of metamorphosis. In one experiment, pediveligers were placed in aquaria with Chatomorpha and held at an average temperature of $27^{\circ} \mathrm{C}$. These larvae reached a length of over $7 \mathrm{~mm}$, and produced abundant egg masses, within three weeks.

In a second experiment, animals from populations feeding on both species of algae were subjected to a reciprocal feeding test. Each animal was measured and placed in a test tube with either a clump of Chatomorpha lineata or a clump of Cladophora gracilis. The test tubes were held seven days in a water bath, and the animals were remeasured at the end of this period. The results (Table 4) show that the population

Table 4

Feeding and percentage growth of Stiliger fuscatus

\begin{tabular}{|cccc|}
\hline Source of animals & Fed Chaetomorpha & Fed Cladophora & $p$ \\
\hline Chaetomorpha & $83 \pm 40 \%$ & $-1.6 \pm 19 \%$ & 0.10 \\
Cladophora & $(\mathrm{n}=4)$ & $(\mathrm{n}=5)$ & \\
& $\begin{array}{c}40 \pm 20 \% \\
(\mathrm{n}=5)\end{array}$ & $\begin{array}{c}13 \pm 17 \% \\
(\mathrm{n}=4)\end{array}$ & 0.01 \\
\hline
\end{tabular}

originally collected from Cladophora grows significantly better when fed Chaetomorpba. The population originally collected from Chaetomorpha also appears to grow better on Chatomorpha, but the difference in growth rate is not statistically significant. This example illustrates the selective value of feeding specificity in the Opisthobranchia.

\section{Tenellia fuscata (GouLD)}

Distribution: Endemic west Atlantic, south to Virginia. This species has been collected at all seven of the Noank collection sites, and also in the Thames River, Montville, Connecticut, at a salinity of $16 \%$. This species seems to prefer warm water for reproduction, and the first animals do not appear in Beebe Cove until May. Occasionally, specimens are collected as late as January, and a few animals probably survive until late spring. Egg masses were observed in nearly all samples of Tenellia, and it is probable that this species reproduces all year. Development of this species is type 2 , and the veligers settle and metamorphose immediately upon hatching.

This species is notable for the wide variety of hydroids upon which it will feed. 
In the Thames River, at a salinity of $16 \%$, it feeds on the low-salinity hydroid Cordylophora lacustris, which grows on Ruppia maritima. At the time of this collection, every hydranth had been eaten, and the slugs were feeding on the remaining hydrocauli. A qualitative sample taken at this time showed a density of 1100 animals per gram of hydroid, and the weight of nudibranchs in the sample equalled $9.1 \%$ of the hydroid weight.

Tenellia also occurs in mats of Cladophora, which cover the bottom of Beebe Cove in early summer. Tenellia crawls along the coarse filaments of the alga searching for the solitary hydroid Ectopleura. This appears to be the optimum food, as the largest specimens of Tenellia $(8 \mathrm{~mm})$ were obtained from this habitat.

Tenellia also feeds on Obelia geniculata, and at sites where the water is relatively warm, may comprise $100 \%$ of the nudibranchs in a sample. Water temperature may influence competition between this species and Tergipes; unfortunately, the thermal tolerance of Tenellia was not analyzed.

\section{Tergipes tergipes (JoHNSTON)}

Distribution: Amphiatlantic boreal, south to New Jersey. This species occurs at all stations at Noank, but most often occurs in association with Obelia geniculata growing either on Laminaria or Zostera. The quantitative samples were taken from Laminaria thalli attached to the ship hull at site 7.

Tergipes is present the entire year at Noank, but most of the Laminaria breaks loose from the ship hull in February, and the regrowth of the algae is not colonized by Obelia until April. Obelia geniculata does grow attached to rocks during this period, and Tergipes with egg masses can be found on these rocks during February, March, and April. Quantitative sampling from this habitat was not possible.

The annual cycle of Tergipes is presented in Figure 9. Mean length reaches a maximum in April and May, soon after the regrowth of the Obelia, and is followed by a sharp decrease in June. Although other trends are unclear, there appears to be a gradual increase in mean and maximum length during the remainder of the year. The drops in this curve follow closely the peaks in population density, suggesting that the decrease in length is the result of the influx of small individuals representing increased recruitment. The gradual increase of length appears to represent storage of energy, which is used in a sudden peak of egg production in May and June (see Figure $9 \mathrm{~b}$ ). The concentration of reproductive activity in this period has obvious value for exploiting the hydroid, as it follows the peak reproductive period of Obelia. Also notable is the secondary peak in November and December, which follows a minor period of reproduction of Obelia in October. Egg production in Tergipes continues for the entire year, as was found to occur for Catriona aurantia.

The predation index in this species, as for the others examined, shows a brief peak in which the ratio approaches $1 \%$. The hydroid in this instance does not show significant damage, although some portions of the colony may be completely stripped of hydranths at this time. The mode of growth, with stolons firmly attached over a wide, flat area, and scattered vertical colonies, distributes feeding activity over a wide area, 
preventing concentration of damage in one area. Further, this peak of nudibranch activity occurs while the hydroid colonies are still actively growing.

This species is sub-annual, with continuous recruitment throughout the year.
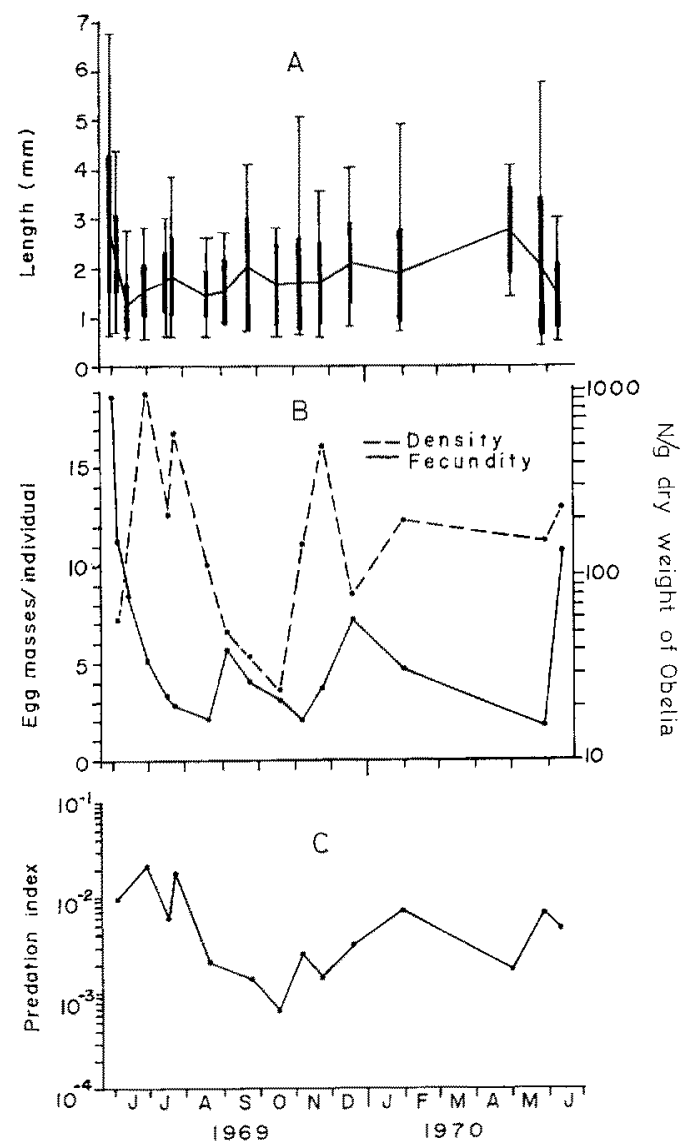

Fig. 9: Annual cycle of Tergipes tergipes. (A) Growth curve, with mean indicated by solid circles, standard deviation by heavy yertical lines, and range by thin vertical lines. (B) Egg production and population density. (C) Predation index (ratio of sample dry weight to Obelia dry weight)

\section{Thermal tolerance}

Graphs of the temperature-respiration rate curves are presented in Figure 10. The $\mathrm{Q}_{10}$, or rate change per $10^{\circ} \mathrm{C}$ temperature change, is presented in Figures 11, 12 and 13. The $Q_{10}$ has been calculated for five degree intervals from the van' $T$ Hoff equation:

$$
\mathrm{Q}_{10}=\left(\frac{k_{2}}{k_{1}}\right) 10 /\left(t_{2}-t_{1}\right)
$$


where $k_{2}$ is the respiration rate at temperature $t_{2}$, and $k_{1}$ is the rate at temperature $t_{1}$ (BĔLEHRÁDEK 1935).

The $\mathrm{Q}_{10}$ for the respiratory rates observed in this study steadily declines from the minimum temperature used in each series of temperatures. As a fractional $\mathrm{Q}_{10}$ results from a decrease in rate, the temperature at which maximum respiration occurs is that at which the $Q_{10}$ equals 1.0. These values have been derived from Figures 11,12 and 13. The temperature at which the maximum respiration rate occurs is usually referred to as an "optimum". The term "optimum" shall be used to refer to this maximum rate, but I wish to emphasize that the optimum for respiration does not imply that this is an

Table 5

Summary of thermal tolerance and acclimatization arranged by zoogeographic region

\begin{tabular}{|c|c|c|c|c|}
\hline Species & $\begin{array}{c}\text { Ambient } \\
\text { temperature }\end{array}$ & Optimum & Difference & $\%$ Acclimatization \\
\hline $\begin{array}{l}\text { Bo reo-s u b a r c ic } \\
\text { Aeolidia papillosa } \\
\text { Ancula gibbosa } \\
\text { Coryphella rufibrancbiali } \\
\text { Dendronotus frondosus } \\
\text { Onchidoris aspera } \\
\text { Oncbidoris fusca } \\
\text { Polycera dubia }\end{array}$ & lis $\begin{array}{c}5^{\circ} \mathrm{C} \\
12 \\
10 \\
10 \\
5 \\
5 \\
5 \\
10\end{array}$ & $\begin{array}{l}18^{\circ} \\
14 \\
18 \\
18 \\
16 \\
19 \\
22 \\
23.5\end{array}$ & $\begin{array}{r}13^{\circ} \\
2 \\
8 \\
8 \\
11 \\
14 \\
17 \\
12.5\end{array}$ & $30 \%$ \\
\hline mean & $7.8 \pm 3.0$ & $18.6 \pm 3.0$ & 10.8 & \\
\hline $\begin{array}{l}\text { Bor e } 1 \\
\text { Acantbodoris pilosa } \\
\text { Catriona aurantia } \\
\text { Tergipes tergipes }\end{array}$ & $\begin{array}{r}2 \\
6 \\
2 \\
13 \\
13 \\
\end{array}$ & $\begin{array}{l}19 \\
25 \\
23.5 \\
25 \\
20\end{array}$ & $\begin{array}{l}17 \\
19 \\
21.5 \\
12 \\
7\end{array}$ & $\begin{array}{l}150 \% \\
14 \%\end{array}$ \\
\hline mean & $7.2 \pm 5.5$ & $22.5 \pm 2.8$ & 15.3 & \\
\hline $\begin{array}{l}\text { Te m p e a te } \\
\text { Cratena pilata } \\
\\
\text { Doris verrucosa } \\
\text { Elysia catulus } \\
\\
\text { Elysia cblorotica } \\
\text { Hermaea dendritica } \\
\text { Stiliger fuscatus }\end{array}$ & $\begin{array}{l}13 \\
18 \\
13 \\
13 \\
18 \\
18 \\
5 \\
11.5 \\
13 \\
20\end{array}$ & $\begin{array}{l}29 \\
30 \\
28 \\
32 \\
32.5 \\
30 \\
19 \\
25 \\
29 \\
33\end{array}$ & $\begin{array}{l}16 \\
12 \\
15 \\
19 \\
14.5 \\
12 \\
14 \\
12.5 \\
16 \\
13\end{array}$ & $\begin{array}{l}20 \% \\
10 \% \\
91 \% \\
57 \%\end{array}$ \\
\hline mean & $14.3 \pm 4.4$ & $28.8 \pm 4.2$ & 14.3 & \\
\hline $\begin{array}{l}\text { Trop ic a l } \\
\text { Facelina sp. } \\
\text { Tridacbia crispata }\end{array}$ & & $\begin{array}{l}32.5 \\
38.5\end{array}$ & & \\
\hline mean & & 35.5 & & \\
\hline
\end{tabular}


optimum temperature for growth or other activities of nudibranchs. Observation of the living animals suggests that the respiratory optimum represents a critical point, beyond which the slugs suffer damage from high temperature. An experimental increase of less than five degrees above the optimum temperature usually results in cessation of movement and release of large amounts of mucus; a few degrees further
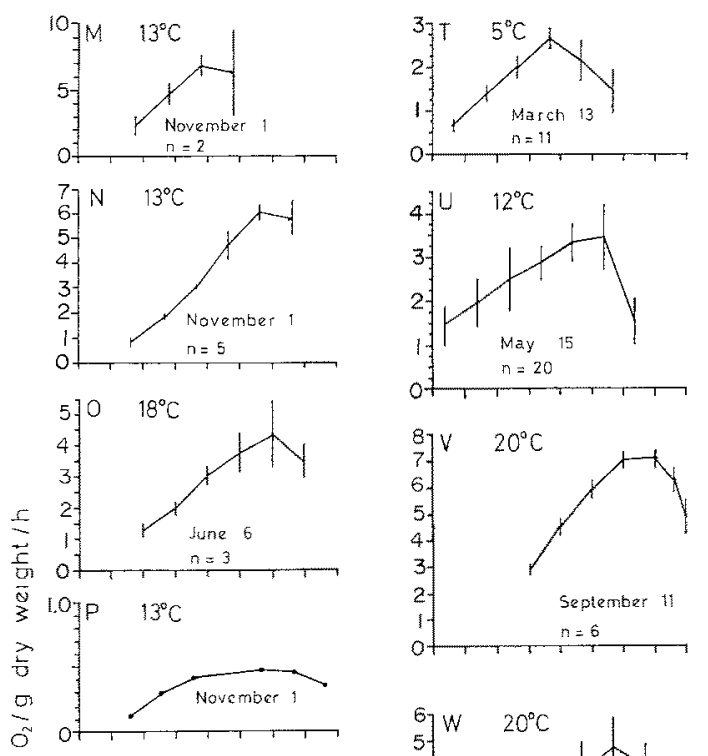

$\bar{E}$
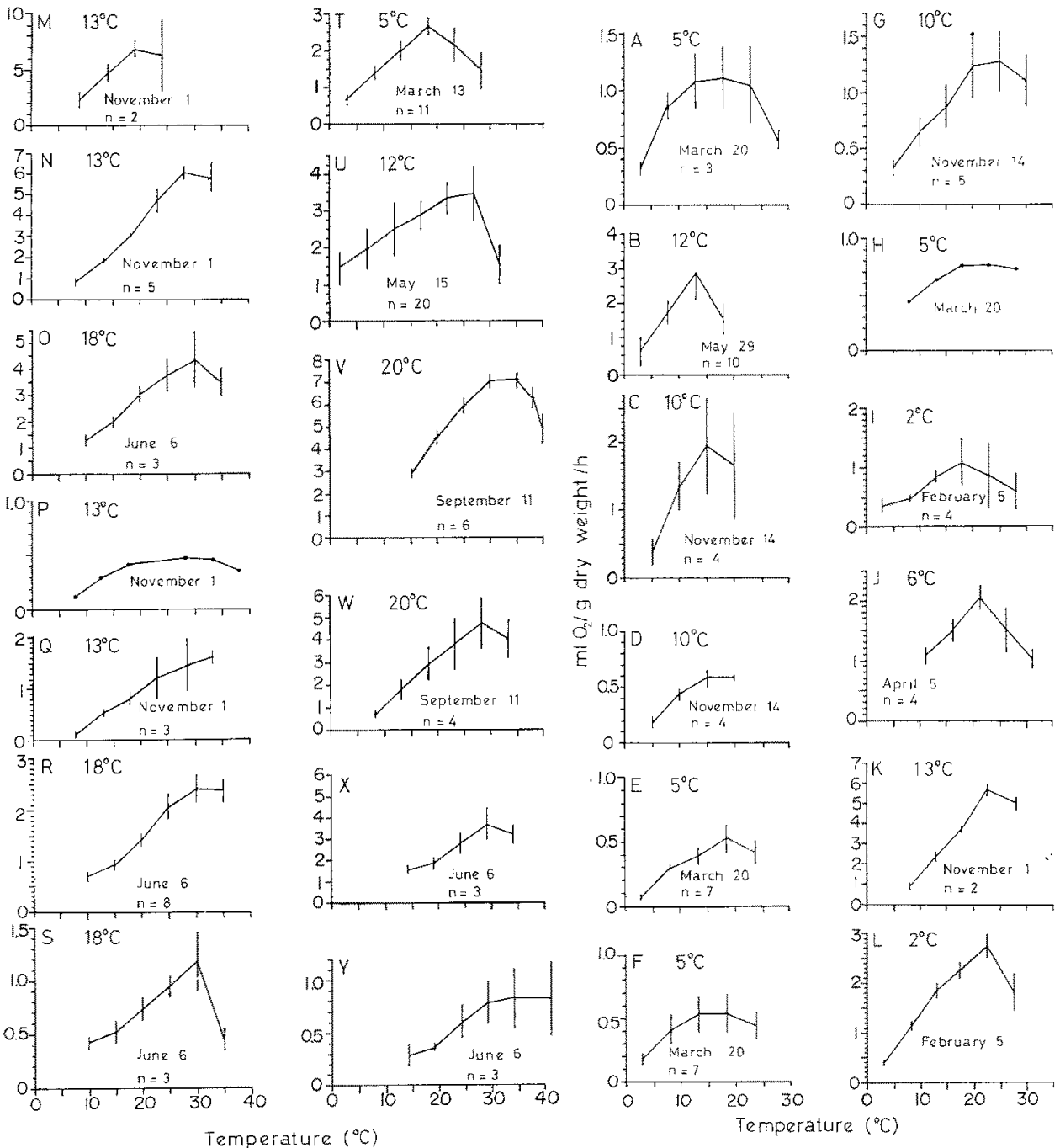

Fig. $10 \mathrm{a}$
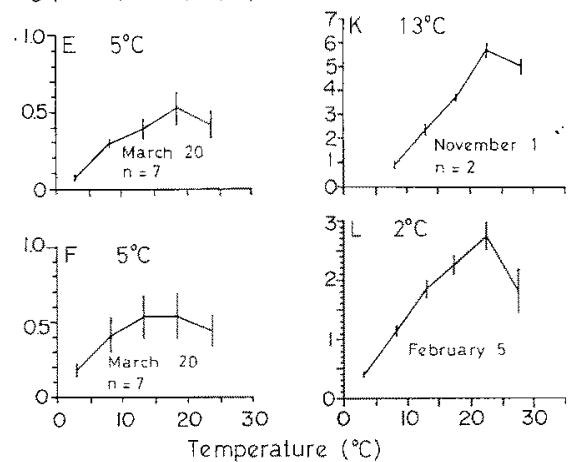

Fig. $10 b$

Fig. 10a: Variation of respiratory rate with temperature. Mean and standard deviations are shown. Boreo-subarctic species: (A) Aeolidia papillosa; (B) Ancula gibbosa; (C) Coryphella rufibranchialis; (D) Dendronotus frondosus; (E) Onchidoris fusca; (F) Onchidoris aspera; (G, H) Polycera dubia. Boreal species: (I, J) Acantbodoris pilosa; (K, L) Catriona aurantia Fig. 10b: Variation of respiratory rate with temperature. Boreal species: (M) Tergipes tergipes. Temperate species: (N, O) Cratena pilata; $(\mathrm{P})$ Doris verrucosa; $(\mathrm{Q}, \mathrm{R})$ Elysia catulus; (S) Elysia chlorotica; $(T, U)$ Hermaea dendritica; (V, W) Stiliger fuscatus. Tropical species: (X) Facelina sp.; (Y) Tridachia crispata 
increase is usually fatal to these animals. A summary of ambient temperatures and optima is presented in Table 5 .

The ability to adapt physiologically to changing temperatures is, in many organisms, reflected by alteration of metabolic rates. This adaptation, or acclimatization, is represented in the respiratory rates of nudibranchs by a shift in the respiratory optimum. These changes are summarized in Table 5 as " $\% / 0$ acclimatization", which has been calculated from the equation:

$$
\frac{\mathrm{O}_{2}-\mathrm{O}_{1}}{t_{2}-t_{1}} \times 100=\% \text { acclimatization }
$$

where $\mathrm{O}_{2}$ and $\mathrm{O}_{1}$ represent the respiratory optima measured for animals collected at ambient temperatures $t_{2}$ and $t_{1}$.

Each of the seven species examined seasonally shows some acclimatization, but only Acantbodoris pilosa shows greater than $100 \%$ acclimatization. This one exception

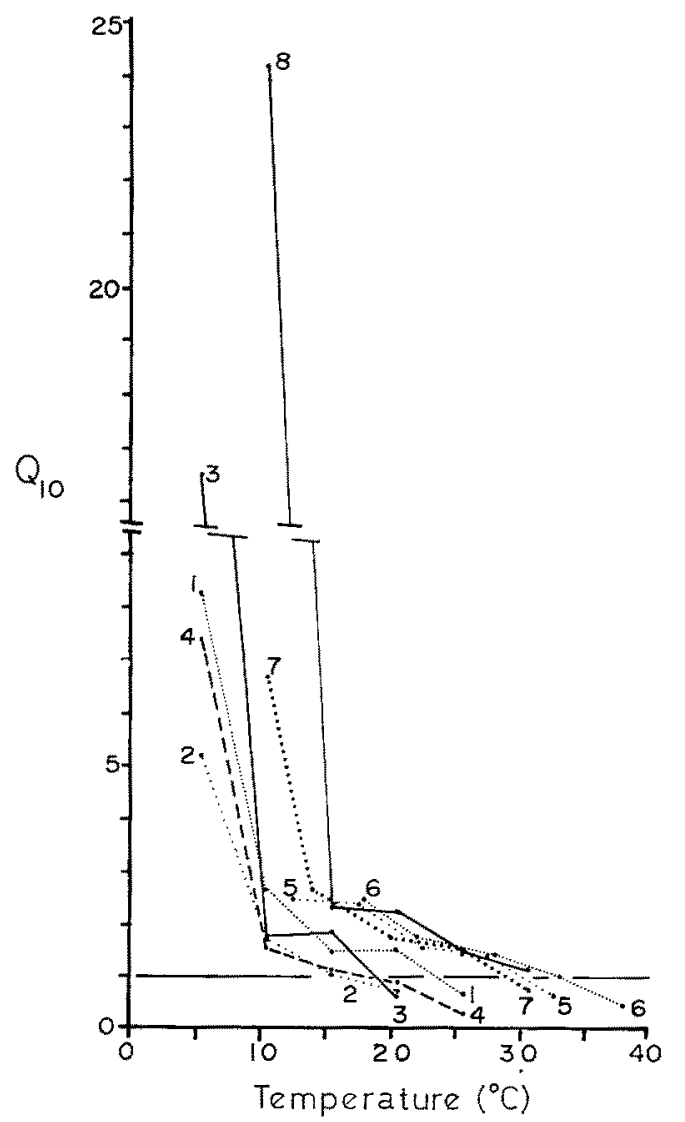

Fig. 11: Variation of $\mathrm{Q}_{10}$ with temperature. The calculated values of $\mathrm{Q}_{10}$ are plotted against the midpoint of the temperature interval selected. (1) Catriona aurantia (Feb.); (2) Onchidoris aspera (March); (3) Onchidoris fusca (March); (4) Aeolidia papillosa (March); (5) Cratena pilata (June); (6) Stiliger fuscatus (Sept.); (7) Stiliger fuscatus (Nov.); (8) Elysia catulus (Nov.) 
may be an artifact resulting from the small difference between ambient temperatures selected. Unfortunately, too few species were examined to discern any correlations between acclimatization ability and zoogeographic distributions.

The respiration curves (Fig. 10) have several features in common. The rate of suboptimal temperatures increases rapidly and nearly linearly. The rate declines sharply at post-optimal temperatures, nearly always at a faster rate than the rate of increase at pre-optimal temperatures.

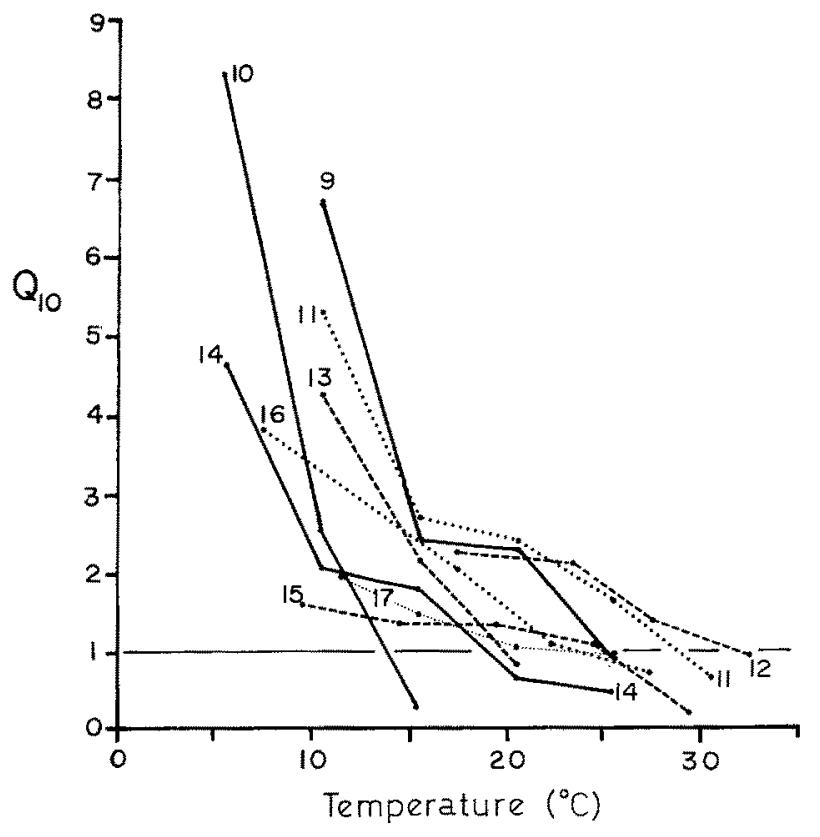

Fig. 12: Variation of $Q_{10}$ with temperature. (9) Catriona aurantia (Nov.); (10) Ancula gibbosa (Nov.); (11) Cratena pilata (Nov.); (12) Elysia catulus (June); (13) Tergipes tergipes (Nov.); (14) Hermaea dendritica (March); (15) Hermaea dendritica (May); (16) Polycera dubia (Nov.); (17) Polycera dubia (March)

The plots of the Q $\mathrm{Q}_{10}$ 's (Figs 11, 12, and 13) also show a high degree of similarity between species. Characteristically, the $Q_{10}$ is very high at low temperatures; there is a sharp inflection in the curve between ten and twenty degrees, with a more gradual slope at temperatures higher than the inflection point. In cases where trials could be repeated seasonally, paired curves are similar in shape, but the values for warm water Q 10 's are higher than for trials representing colder ambient temperatures. When zoogeographic groups are compared, the boreo-subarctic species (Coryphella rufibranchialis, Aeolidia papillosa, Dendronotus frondosus, Oncbidoris aspera, O. fusca, Ancula gibbosa) have the highest $\mathrm{Q}_{10}$ 's at the lowest temperatures, indicating that this group is the most sensitive to temperature changes. The boreal species (Catriona aurantia, Tergipes tergipes, Acanthodoris pilosa) all have curves intermediate between the boreo-subarctic and the temperate (Cratena pilata, Elysia catulus, Elysia chlorotica, Hermaea 
dendritica, Stiliger fuscatus) groups. The Sacoglossa (Elysia, Hermaea, Stiliger) have somewhat flatter slopes and lower $\mathrm{Q}_{10}$ 's at a given temperature than do the Nudibranchia, probably reflecting the adaptation of the Sacoglossa to a high subtidal habitat, where light and algal densities are highest but temperatures are more variable.

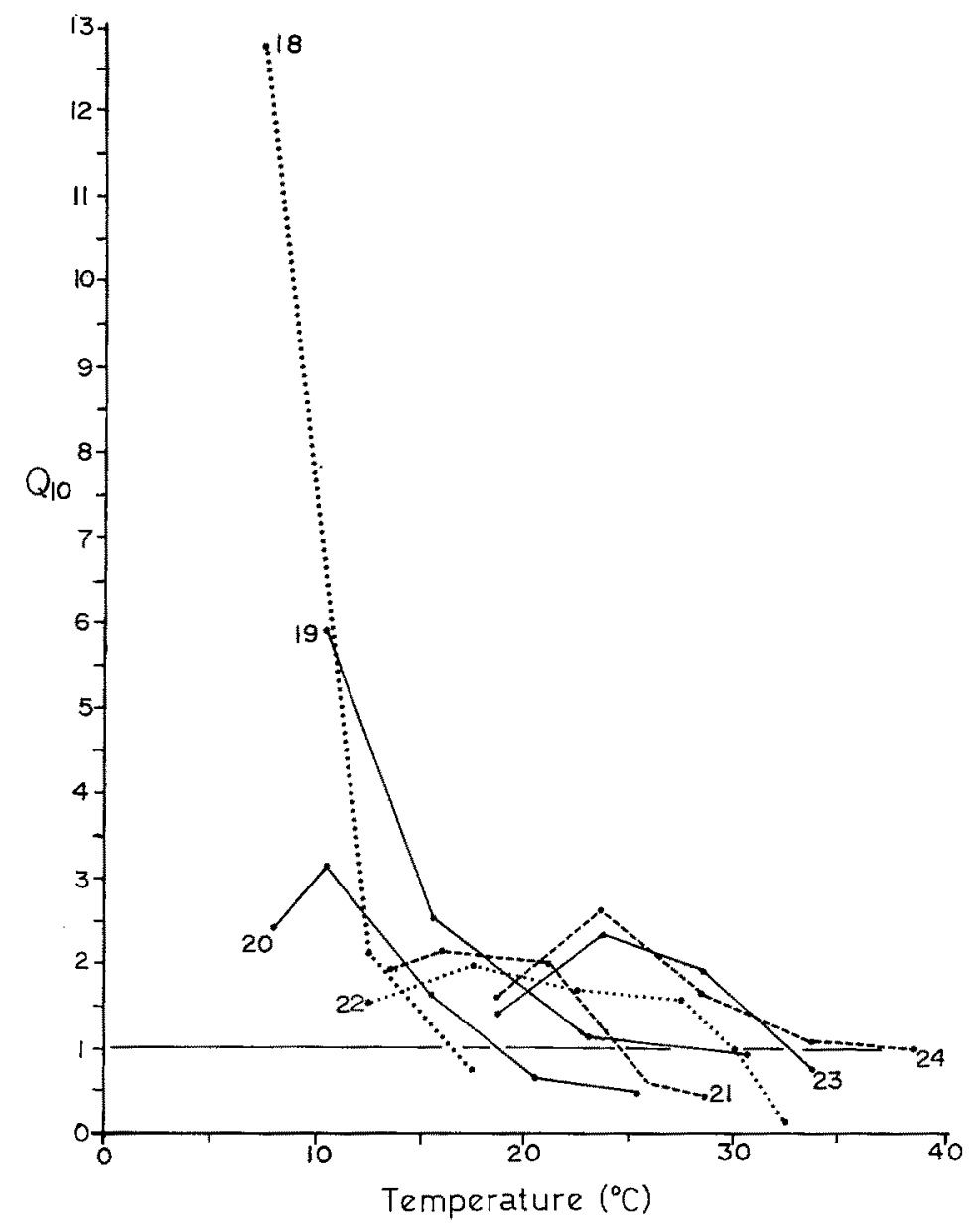

Fig. 13: Variation of Q10 with temperature. (18) Coryphella rufibranchialis (Nov.); (19) Doris verrucosa (Nov.); (20) Acantbodoris pilosa (Feb.); (21) Acanthodoris pilosa (April); (22) Elysia cblorotica (June); (23) Facelina sp. (June); (24) Tridachia crispata (June)

\section{DISCUSSION}

Nudibranchiate molluscs characteristically feed on marine Aufwuchs (epifauna fouling organisms) and rarely on other types of organisms. Because of the intimacy of this feeding relationship, a discussion of nudibranch ecology must consider the biology of the food species. 
Fouling communities show many of the characteristics of larger-scale ecosystems, although structure is usually somewhat simplified and rates of ecological processes are accelerated. Changes in Aufwuchs community structure follow a successional pattern, with a progressive, orderly series of changes ultimately leading to relative stability.

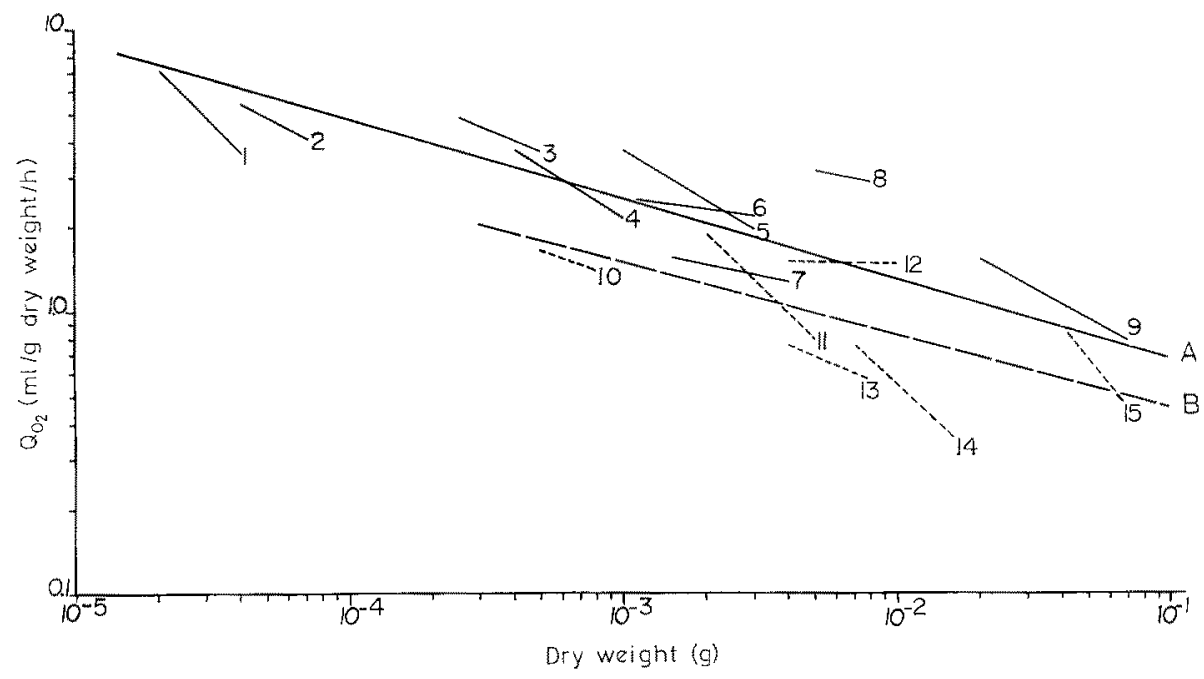

Fig. 14: Relationship of respiration rate $\left(18-21^{\circ} \mathrm{C}\right)$ to weight. All solid lines indicate ceratal species; all broken lines indicate non-ceratal species. $A$ and $B$ are the regression lines of the minimum and maximum sample values of each species: $\log Q_{A}=-0.25 \log W+0.93$; $\mathrm{r}_{\mathrm{A}}=-0.88 ; \log \mathrm{QB}=-0.26 \log \mathrm{W}+0.69 ; \mathrm{rB}=-0.68 ;(1)$ Tergipes tergipes; (2) Tenellia fuscata; (3) and (4) Stiliger fuscatus; (5) Catriona aurantia; (6) and (7) Hermaea dendritica; (8) Cratena pilata; (9) Aeolidia papillosa; (10) Elysia catulus; (11) Polycera dubia; (12) Acanthodoris pilosa; (13) and (14) Onchidoris aspera; (15) Oncbidoris fusca

Temporary seasonal changes may be superimposed upon this pattern, especially on artificial substrates, leading some authors (SCHEER, 1945) to label these changes "seasonal progression." However, some natural fouling communities do not show pronounced seasonal effects, and even early stages of seasonal progressions show uniform, predictable changes. The specific organisms involved vary tremendously in different localities and microhabitats, but a general pattern has been noted by various authors (Huvé, 1953; Scheer, 1945; McDougall, 1943; Turner et al., 1969; Haderlie, 1969). A clean surface rapidly acquires an initial organic film and bacterial growth ensues within 24 hours; diatoms bloom within one week, and macroscopic algae and hydroids appear within two to three weeks. Hydroids rarely dominate the community for more than a few weeks, and are rare after six months, being replaced by Bryozoa, Porifera, ascidians, or other organisms. The latter groups are relatively stable, and may colonize surfaces for several years before climatic stresses (temperature extremes, turbulence) return the system to a bare substrate.

Several lines of evidence suggest that competitive interactions may lead to elimination of hydroids from Aufwuchs communities and replacement by other forms. Substrate availability has been shown to be an important limiting factor for benthic 
invertebrates. This is especially important for Aufwuchs forms, where a hard, permanent attachment site is critical to survival. Competition for attachment sites is keen, and has led many fouling organisms to evolve similar mechanisms conferring competitive advantages. Stolonic or erect, arborescent, asexual growth occurs commonly in Porifera, hydroids, Bryozoa, Entoprocta, and ascidians. This adaptation permits maximal growth following a single successful attachment by a larval form, and also tends to keep a portion of the colony spatially separated from other Aufwuchs forms, decreasing competition for food and oxygen. Stebring (1971) mentions a more subtle advantage: growth rates of colonial forms do not decline with age, providing a competitive advantage over non-colonial forms.

Differences in growth rates and life spans also affect competitive interactions. Species with slow growth and long life will ultimately out-compete rapid growing, short lived species, if other factors are equal. Unfortunately, few data are available on in situ growth and longevity of Aufwuchs species. McDougall (1943) gives the lifespan of the hydroid Tubularia as five weeks to several months; Pennaria, four months; and Eudendrium, six months. Bryozoa live substantially longer: twelve years for Flustra foliacea (STEBring, 1971) and several years for Bugula (GRAve, 1930). Solitary ascidians in non-tropical waters live from five months to $3^{1 / 2}$ years, while colonial forms may live up to five years and usually more than one year (MILLAR, 1971).

Antibiotics and contact inhibitors may also be significant in competitive interactions. These substances occur in many benthic organisms, and may affect community dominance by killing competing larvae, or through suppression of growth of competing species. STEBBING (1973) found that several species of Bryozoa cause cessation of growth of zooids in adjacent colonies of different species. The ascidian Botryllus was found to overgrow the bryozoan Electra and the polychaete Spirorbis. The stolons of the hydroid Dynamena were regularly overgrown. Overgrowth caused death of Spirorbis, but rarely affected growth of the hydroid, which is largely arborescent. However, overgrowth of the substrate by the Bryozoa mentioned (Electra, Alcyonidium) would eventually exclude hydroids from the community as all bare surfaces became covered, preventing planula attachment. If this information can be generalized to most fouling communities, then hydroids have a considerable competitive disadvantage relative to animals characteristic of later seral stages.

In the energy budget of a population, diversion of energy into defensive adaptations must occur at the expense of growth or reproduction. The rapid growth of hydroids is achieved through a decrease in competitive ability, but permits rapid colonization and exploitation of available bare substrates. These aspects are characteristic of early successional species in general (EMLEN, 1973). Sponges, Bryozoa, and colonial ascidians grow more slowly, but usually have annual or perennial growth and usually dominate mature fouling communities.

Predation effects can readily alter the basic pattern of succession. Removal of hydroids, for example, might speed colonization by other groups. The stability of a predator-prey system increases when more prey species are available to a predator (MAcArThur, 1955), and according to Darnell (1970) community stability also increases if "regulator species" (predators with broad food tolerances feeding on the most easily obtained prey) are present. Nudibranchs are markedly stenophagous, and 
appear to contribute to instability in fouling communities through damage to major components of the community.

In several of the life cycles described, severe damage to the host species was noted: Catriona on Tubularia, Stiliger on Chaetomorpha and Cladophora, Eubranchus on Obelia, Hermaea on Codium, Polycerella on Bowerbankia, and Tenellia on Cordylophora and Ectopleura. Each of these species caused severe damage to the host species during population peaks, usually after the predation index exceeded one percent. Sloughing of arborescent food species causes disappearance of nudibranch populations, as the food organism also serves as a microhabitat. Overgrazing immediately prior to disappearance has also been reported by Swennen (1961), MLller $(1961,1962)$ and Chambers (1934).

Overgrazing is not characteristic of those nudibranchs which feed on non-transient food populations, such as barnacles, tunicates, sponges, and Bryozoa (THompson, 1964). These nudibranchs tend to be annual or biannual species, reach large size, and have restricted periods of egg production. Minimal damage to the food species results, and the larger size of the predator confers added mobility which tends to disperse feeding activity over a broader area.

Clearly, nudibranchiate molluscs can be divided ecologically into two groups based on time of appearance in the successional process. These characteristics are summarized in Table 6. Exploitist species (characteristic of early seral stages) have very rapid growth, short life cycles and early maturation. The rapidity of the life cycle is rivaled by no other group of molluscs. ORTON (1914) showed that Eubranchus

Table 6

Characteristics of early and late succession nudibranchiate molluscs

\begin{tabular}{|c|c|c|}
\hline Characteristics & Exploitist (eariy stage) & Strategist (late stage) \\
\hline food supply & transient & stable \\
\hline seral stage & early & late \\
\hline maximum size & small & large \\
\hline egg production & $\begin{array}{l}\text { continuous, initiated at small } \\
\text { size }\end{array}$ & $\begin{array}{l}\text { discontinuous, usually once annu- } \\
\text { ally, followed by death }\end{array}$ \\
\hline recruitment & continuous & confined to brief period \\
\hline growth cycle & $\begin{array}{l}\text { asynchronous, very rapid } \\
\text { subannual }\end{array}$ & synchronous, slow annual \\
\hline reproductive strategy & & $\mathrm{K}$ \\
\hline population stability & highly unstable & stable, except following spawning \\
\hline gut form & $\begin{array}{l}\text { usually cladohepatic } \\
\text { most Aeolidacea, some }\end{array}$ & $\begin{array}{l}\text { usually holohepatic } \\
\text { most Doridacea, some Arminacea, }\end{array}$ \\
\hline 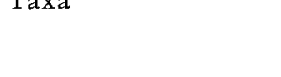 & $\begin{array}{l}\text { Arminacea, some Dendrono- } \\
\text { tacea, some Sacoglossa. }\end{array}$ & some Dendronotacea \\
\hline
\end{tabular}

exiguus, E. pallidus, and Galvina picta spawned in less than six weeks (post-larval). RASMUSSEN (1944) grew Tenellia pallida to maturity in three weeks; BAYER (1963) reported that Fiona pinnata grew from $8 \mathrm{~mm}$ to maturity in only four days, and RAO (1937) reported that Stiliger galopalai matured in 16 days. Stiliger fuscatus in the present study matured in less than three weeks, increasing in biomass from 20 to 
$1000 \mu \mathrm{g}$. The growth rates of Tergipes, Catriona and Hermaea are also very rapid, although not directly estimable from the data given here.

An increase in the pre-reproductive growth rate should be attributable to one or more of the following causes: (1) a higher metabolic rate with consequently more rapid feeding activity and synthetic reactions; (2) increased assimilation efficiency or rate; (3) decrease in the homeostatic portion of total metabolism; (4) decrease in rate of excretion of high energy compounds. Of these possible mechanisms, (3) is presumably fixed at minimum through natural selection for all organisms, and (4) does not present a reasonable alternative as nudibranchs do not excrete significant amounts of such compounds that a decrease would greatly enhance growth. Feeding specificity and selective grazing represent adaptions of (2), but these are common to both annual and subannual species. There is evidence, however, that increased metabolic and assimilation rates allow the subannual species to grow at a faster rate. These differences can be ascribed to a unique anatomical adaptation, found only in certain types of nudibranchs: the ceras (plural cerata), which functions in both respiration and digestion.

Gut modification, together with dietary specialization, represents one of the major evolutionary trends within the Opisthobranchia. It is reasonable, therefore, to assume that differences in gut structure may relate to changes in assimilation efficiency. One obvious adaptation is the branching of the midgut gland, a trend found to varying degree in several groups of nudibranchs. By increasing the total surface area of the gut, and exposing more area to the circulating hemolymph, digestion and absorption rates are significantly increased.

All Doridacea have a compact, unbranched (holohepatic) midgut gland, which is the principal site of absorption (MORSE, 1968). However, some Dendronotacea, some Arminacea, all Aeolidacea and some Sacoglossa have a branched (cladohepatic) midgut gland, with diverticula extending into dorsal papillae (cerata sensu stricto). Intermediate stages exist, with branching of the midgut gland but without extension into cerata. The displacement of the diverticula into the cerata must present some selective advantage. Absorption is improved by physical separation of the diverticula; this separation is otherwise limited by the dimensions of the visceral mass. Thus, the area of the digestive system exposed to the hemolymph is significantly increased. An interesting parallel occurs in the Elysiidae, where cerata are absent but digestive diverticula and blood vessels both extend into the parapodia.

A second function of the ceras is to increase the surface area for respiratory uptake of oxygen. If rate of oxygen uptake is a limiting factor for metabolic rate, then an increase in respiratory surface area should increase this rate. Figure 14 compares respiration rates of ceratiform and non-ceratiform species. The regression lines have equal slopes $\left(F_{a}=0.06 F_{.05(1,26)}=4.22\right)$, but have different means (level of significance lies between $5 \%$ and $10 \%$, with $F_{.05(1,27)}=4.21>F=3.15>F_{.10(1,27)}=2.9$. This suggests that respiratory rates for species with cerata may be higher than those which lack cerata at similar temperatures. Futher sampling should confirm this relationship.

Consideration of surface-to-volume ratios suggests that cerata increase the metabolic rate above maintenance metabolism levels. Papillae should be of more importance to the hemispherically shaped dorids than to the cylindriform aeolids if they served only to satisfy minimum homeostatic respiration requirements. However, most 
dorids have true gills, of much smaller total surface area, and lack papillae. The observed increase in overall respiratory rate in ceratiform species probably represents an increase in nonhomeostatic metabolism.

In several very small aeolidiform molluscs, the cerata actively pulsate, rapidly circulating the hemolymph past the digestive diverticula. This was reported for the sacoglassans Alderia modesta and Stiliger (Marcus, 1956), and I have observed pulsation in Tenellia (unpublished). This may further increase absorption and respiratory uptake, and account for the very rapid growth observed for Stiliger.

The scarcity of data makes it difficult to relate the possession of cerata to rapid growth and subannual cycles in the Arminacea and Dendronotacea. In the Arminacea, Armina feeds on Alcyonaria, and has a branched midgut gland but lacks cerata (Hyman, 1967). Because of its large size, this genus is presumably an annual. The Antiopellidae are smaller in size, feed on hydroids and Bryozoa (Thompson, 1964; SCHMEKEL, 1968), have cerata, and appear to be subannuals. In the genus Dendronotus (Dendronotacea) different species have variable numbers of true cerata, with additional papillae lacking diverticula. The largest species, the giant $D$. iris is probably an annual and feeds on the anemone Cerianthus (RoBrllard, 1971). The smaller species, as $D$. frondosus, generally feed on hydroids, but information on lifespan is not available for most species. The Dotoidae feed an hydroids, have true cerata, and are small, subannual forms with continuous recruitment (MnLler, 1962). The Tritoniidae are generally large, annual species (SCHMEkel, 1968; Mrller, 1962), lack cerata (HYMAn, 1967), and feed on Alcyonaria (THompson, 1964). Thus the general relationship of small size, subannual life cycle, possession of cerata, and feeding on hydroids appears to hold true for most groups.

Rapid growth and early sexual maturation at a small size are quite valuable as characteristics ensuring successful exploitation of transient food sources. Maximum size is determined by the time of initiation of egg production, which diverts a considerable fraction of the energy budget from growth to gonad output. In the cycles of Tergipes, Catriona and Stiliger egg production begins at a very small size and gradually increases, with seasonal peaks of egg production. In all of the species studied, a size decrease follows the peak of egg production, and is in turn followed by the disappearance of many of the adults. Similar effects were shown by MrLier (1962), Thompson (1964), and Potrs (1970). Thus, egg production may not only halt growth, but may also cause a decrease in size, probably through resorption of somatic tissue to provide additional gamete material. The rapid production of such large amounts of egg material must place a great physiological strain upon the adult slugs. Death is a normal occurrence following spawning of annual species, and probably accounts for the sudden disappearances of these populations. CHAmbers (1934) states that death does not always follow spawning. His observations, however, were based on finding that a few slugs survived atter production of two or three egg masses. Certainly, spawning of a few egg masses need not lead to mortality, but a prolonged period of egg production would exhaust an animal's energy reserves.

As most nudibranchs have limited mobility once they settle, they can feed only on those food sources in their immediate vicinity. In most cases, only one food species is likely to be available to the slug. This predator-single-prey system of the nudibranchs 
is certainly a highly unstable one in many cases. As the life cycle analyses show, the rapid increase of a nudibranch population frequently leads to the destruction of its microhabitat. Before breakdown of the habitat is completed, however, a large number of larvae has been produced. These larvae serve to colonize other hydroid communities, probably at considerable distances from the parent population.

The hypothesis that nudibranchs are ectoparasites has been suggested by SwENNEN (1959). They do indeed possess the characteristics of parasites, including an obligate physiological dependence on the host, significant damage to the host, an extended period of contact with the host, and a high degree of host specificity. In several of the described life cycles, activity of the nudibranchs leads to nearly total destruction of the host.

Sloughing of Tubularia colonies is mentioned by MACDougall (1943) and attributed, in part, to high temperature. Temperature was also credited with causing sloughing by Morse (1909) and Moore (1939). MacDougall (1943); however, noted that some settlement and growth of Tubularia continued at the highest water temperatures (above $27^{\circ} \mathrm{C}$ ), and that the colonies were subject to heavy predation by nudibranchs. Some growth of Tubularia continues all year at Noank. Even if death of the colonies is due partly to temperature, it is likely that feeding by nudibranchs in many cases contributes to the death of the host hydroid if near-lethal temperatures are encountered.

Break-up of algae colonized by Sacoglossa, similar to the fragmentation of Cladophora and Chaetomorpha at Noank, has been reported by Miller (1961, 1962) to occur in early summer, when feeding activity of the slugs is probably the highest. The evidence strongly suggests that break-up of fouling communities is frequently a result of activity by nudibranchs. SWENNEN (1961) mentions overgrazing by Tergipes as a cause of disappearance of the hydroid Laomedea. CHAmbers (1934) also mentions overgrazing prior to disappearance of nudibranch populations.

The nudibranchs occurring at Noank appear to be relatively non-selective predators. Seven of the nineteen Nudibranchia $(37 \%)$ examined feed on two or more species of hydroids at Noank (Table 1), despite the low number of potential food species found there. While many of the British nudibranchs reported by THOMPson (1964) feed on two or more species of prey, these observations are based on a much larger geographical range (Europe and the British Isles) and a much higher diversity of potential prey species. Two of the five Sacoglossa studied $(40 \%)$ also feed on two species. In each case the two algae are from different genera, contrary to the opinion of GONOR (1966) that feeding of the Sacoglossa is always limited to algae of a single genus. This generalization of feeding of the Nudibranchia and Sacoglossa in southern New England may represent an adaptation to unstable food sources. The chances of survival in the event of seasonal scarcity of one food species are enhanced if several potential food sources are utilized. However, some foods are obviously better than others, as has been shown for Stiliger fuscatus (Table 4).

Several food species of the southern New England fauna serve as food for two or more species of nudibranchs. These include Tubularia crocea, Obelia geniculata, Bowerbankia gracilis, and Cryptosula pallasiana. The effects of interspecific competition for food are slight, however, because of temporal separation of populations. In nearly every example of potentially competitive species, peak populations occur at 
different times of the year. For example, Cratena pilata and Catriona aurantia both feed on Tubularia crocea. Cratena has maximum activity in autumn months, while Catriona has its maximum activity in early summer (Fig. 5). Differences in thermal tolerance, as indicated by respiratory optima (Table 5), readily account for this temporal separation, as Cratena pilata has a higher optimum than Catriona, corresponding to late summer temperatures.

Of the fewer than twenty-five species of Nudibranchia and Sacoglossa from southern New England, only eight species (Catriona aurantia, Cratena pilata, Elysia catulus, Eubranchus exiguus, Hermaea dendritica, Stiliger fuscatus, Tenellia fuscata, and Tergipes tergipes) occur regularly and in abundance each year, and of these eight species, only three (Catriona, Elysia catulus, and Tergipes) can be readily collected year-round. This fauna thus consists mostly of boreal and temperate species which are predominantly seasonal in occurrence. Peaks in reproductive activity and population size, in nearly all of these species, occur in late spring and early summer months. Only two species, Polycerella emertoni and Doris verrucosa, have their maximum activity in late summer or early autumn.

Eight of the species occurring at Noank (Acantbodoris pilosa, Ancula gibbosa, Dendronotus frondosus, Eubranchus exiguus, Oncbidoris aspera, Onchidoris fusca, Polycera dubia, and Polycerella emertoni) have an interval of at least five months between disappearance of the adults and the first appearance of the juveniles. While the duration of the planktonic phase of larvae with type 1 development has not been determined, it is highly improbable that the planktonic phase is as long as five months. Hence, it must be concluded that even though these species successfully reproduce at Noank, their larvae rarely settle and metamorphose locally, and that those larvae which do settle at Noank each year are produced elsewhere. The cold-water species (all but Polycerella) listed above appear to have populations in northern New England which are present most of the year. Larvae produced in Maine or Massachusetts could easily be transported south to the Connecticut coast by south-moving coastal currents, particularly if the planktonic swimming phase were several weeks in length. Transport of nudibranch larvae over 500 miles from the hatching site has been reported by Mrneikovsky (1960). While insufficient data are available for Polycerella emertoni, it is possible that a self-sustaining population is present as far north as New Jersey (Chambers, 1934; Franz \& Clark, 1972).

While Hermaed dendritica and Stiliger fuscatus have populations at Noank for the entire year, the recruitment peaks occur when the population levels of the adults are too low to produce sufficient larvae to account for these peaks (Figs 7 and 8). Hence, while some of the larvae may originate from Noank populations, the major contribution to recruitment is from allochthonously produced larvae. As both peaks of recruitment occur with rising temperature, it is reasonable to assume that the sudden peaks are the result of masses of larvae which follow northward-moving currents. Larvae may mature in the plankton, but are unable to settle and metamorphose except in the presence of the food species. When the larvae-bearing currents reach shore, presence of the food species stimulates the larvae to settle, and a sudden peak of recruitment occurs. A less-likely possibility is that the populations are supplied by larvae produced in nearby salt ponds or marshes where the water temperature rises in 
advance of that of larger bodies of water. However, examination of these areas has not produced evidence of sufficient populations (personal observation).

Maximum occurrence of most nudibranch species in southern New England occurs in a zone extending from low subtidal to a depth of about $3 \mathrm{~m}$ below MLW. Localization of nudibranchs in this narrow zone appears to be due to concentration of food species in this region. Many of the food species also occur well up into the intertidal zone, but extreme variation of air temperatures apparently prevents most nudibranchs from utilizing these. Some food species, such as Tubularia crocea and Obelia geniculata, grow as deep as $25 \mathrm{~m}$ in Long Island Sound, but nudibranch population densities are substantially lower at these depths. Lower temperatures at these depths may limit population size by barring passage of larvae through the thermocline, as noted by 'THORSON (1966).

No Nudibranchia or Sacoglossa with type 3 development occur at Noank. Of twenty species examined (Table 3 ) only two $(10 \%)$ have type 2 development, and eighteen $(90 \%)$ have type 1 development. While species with type 1 development predominate in southern New England, the European fauna shows a greater tendency toward forms with types 2 and 3 development. Of thirty European species summarized by THompson (1967), twenty-one (70\%) have type 1 development, five $(17 \%$ ) have type 2 development, and four $(13 \%)$ have type 3 development. A similar trend exists in northern New England, with at least three species possessing type 3 development. Coryphella salmonacea, distributed northward from Massachusetts, and Corypbella stimpsoni, from Maine, have type 3 development (MOrse, 1969), as does Cadlina laevis from northern Maine (Morse, personal communication).

Where climate and food supply are relatively stable, as in the eastern Atlantic and northern New England, there appears to be some selection toward species with type 3 development. Direct development of the larvae enhances their survival, but is of evolutionary value only if a dependable food supply is available for the larvae at the time of hatching and if the larvae will not be exposed to lethal temperatures at the site of egg deposition. Since food supplies at Noank are unstable, and high subtidal locations where most species occur are exposed to possibly lethal temperatures, species with direct development are less likely to survive. The type 1 development of Dendronotus frondosus in southern New England, where type 2 development is reported from Europe by THompson (1967), illustrates the selective force favoring type 1 development in areas with fluctuating climate and unstable food supplies.

Species with type 2 development would appear of necessity to have year-round populations, as dispersal from a distant population would be slow. While Catriona obviously is present all year, Tenellia is not seen most of the year. An undetected food source may exist which sustains this species through the winter months.

The northwest Atlantic nudibranch fauna possesses a notably low species diversity. Southern New England contains a combined total for the orders Nudibranchia and Sacoglossa of about twenty-eight species (Franz, 1970). By contrast, areas such as the British Isles, with 90 species (WINCKworTH, 1932, 1951), the Gulf of Naples, with 112 species (SCHMEkel, 1968), and California, with at least 75 species, (SMITH \& GoRDON, 1948; LANCE, 1961; MARCus, 1961b) have a substantially higher species diversity. The major difference between the northwestern Atlantic coast and the northeastern 
Pacific and northeastern Atlantic coasts is climatic stability. Annual temperature variation in shallow waters of southern New England may approach $27^{\circ} \mathrm{C}$, while comparable annual variation in Puget Sound is only $5.5^{\circ} \mathrm{C}$ (SANDERs, 1969), 7.5 ${ }^{\circ} \mathrm{C}$ in the Irish Sea (MrlLer, 1961), and $11^{\circ} \mathrm{C}$ in the Gulf of Naples (Schmekel, 1968). The "stability-time hypothesis" of SANDERS (1968) predicts that as physical fluctuations of an ecosystem become increasingly severe, species numbers will decrease, resulting in lower diversity. SANDER's hypothesis can be readily applied to explain the lower diversity of the nudibranch fauna in the western Atlantic.

An examination of thermal sensitivity of nudibranchs may provide a more exact explanation of the factors which favor low diversity. Several species of nudibranchs which occur in southern New England do appear to experience thermal mortality. Acantbodoris pilosa, Ancula gibbosa, Dendronotus frondosus, Coryphella rufibranchialis, Facelina bostoniensis, Onchidoris aspera, Onchidoris fusca, and Polycera dubica all either disappear from field samples with rising summer temperatures or do not appear until winter temperatures approach. As shown by experimental determination of thermal tolerances, all of the species examined can tolerate temperatures to within a few degrees of $0^{\circ} \mathrm{C}$, although many of them become dormant at low temperatures. Acanthodoris pilosa and Onchidoris fusca are able to tolerate temperatures of $19^{\circ} \mathrm{C}$ and above, even when adapted to low ambient temperatures. Corypbella rufibrancbialis, Dendronotus frondosus, Onchidoris aspera, and Ancula gibbosa seem highly likely candidates to suffer thermal mortality, as evidenced by the small difference between the ambient and optimum temperatures. The seasonal mortality of Acantbodoris, Polycera, and Onchidoris fusca appears to be due to factors other than thermal mortality. Tergipes also shows little difference between the ambient and maximum temperatures tolerated. Unlike the other species listed above, however, Tergipes produces several generations per year. Successive generations can possibly adapt to higher temperatures better than a single generation. Such a mechanism was suggested by MACDougall (1943) to explain tolerance by new growth of Tubularia crocea to temperatures which were lethal to the parental generation. However, inability to adapt beyond a maximum temperature is indicated by the observation that in the warmest part of Noank Harbor in late summer, Tenellia fuscata sometimes completely replaces Tergipes on growth of Obelia geniculata.

The maximum temperatures tolerated correlate, in general, with the zoogeographic distributions of the species examined (Table 5). The boreo-subarctic species (Coryphella rufbrancbialis, Ancula gibbosa, Oncbidoris aspera, O. fusca, Polycera dubia, Dendronotus frondosus, and Aeolidia papillosa), from samples with mean ambient temperature of $8^{\circ} \mathrm{C}$, tolerate a mean maximum temperature of $18^{\circ} \mathrm{C}$. The boreal species (Catriona aurantia, Tergipes tergipes, and Acantbodoris pilosa), from samples with a mean ambient temperature of $7^{\circ} \mathrm{C}$, tolerate a mean maximum temperature of $23^{\circ} \mathrm{C}$. Temperate species (Cratena pilata, Elysia catulus, E. chlorotica, Stiliger fuscatus, and Hermaea dendritica), from samples with a mean ambient temperature of $17^{\circ} \mathrm{C}$, tolerate a mean maximum temperature of $30^{\circ} \mathrm{C}$.

The $\mathrm{Q}_{10}$ 's correlate well with the distributions of the species examined. The curves for boreo-subarctic, boreal, and temperate species fall into well-defined groups, according to the ranges of sensitivity to a given temperature. 
Most of the nudibranchs studied show high $\mathrm{Q}_{10}$ 's at low temperatures (Fig. 11, 12, and 13). As a high $\mathrm{Q}_{10}$ indicates a large change in relative activity of an organism, nudibranchs might be termed sensitive to temperature; not necessarily in the sense of causing mortality due to temperature change, but rather in the sense of rate of change of activity with temperature. The high $\mathrm{Q}_{10}$ at low temperature relates to relative dormancy observed in the slugs at low temperatures. With a few degrees rise in temperature, the slugs begin active movement. Activity continues to increase to within a few degrees of the maximum temperature tolerated, beyond which activity rapidly declines and death quickly ensues. This high degree of temperature sensitivity probably accounts in part for the apparent rapidity of population changes, since a relatively small temperature change can cause a large change in growth rate or rate of metamorphosis. The sudden burst of recruitment of Stiliger fuscatus might be related to temperature changes in June and July, if temperature changes act as a signal which triggers settling behavior. High sensitivity may also serve as a strong signal for the initiation of reproductive behavior, which may synchronize reproduction of an entire population at the same time, thus ensuring maximum reproductive success. The rapid decline of the $\mathrm{Q}_{10}$ of Catriona to about $15^{\circ} \mathrm{C}$ (Figs 11,12 ) correlates with the peak of egg production from May to June, during which temperature increases from $5^{\circ}$ to $15^{\circ} \mathrm{C}$. Similar correlations can be seen for the egg laying peaks and $\mathrm{Q}_{10}{ }^{3}$ s of Tergipes tergipes, Hermaea dendritica, and Elysia catulus. High thermal sensitivity might also have adaptive value if it served to limit feeding activity of the nudibranchs to periods when prey species are actively growing.

The high thermal sensitivity of the species examined can certainly help to explain the low diversity of nudibranchs in the western Atlantic. As suggested by Lemche (1941), a period of increased temperatures is probably necessary for successful reproduction of most temperate, boreal, and boreo-subarctic species, and summer temperatures encountered in southern New England are lethal to several of the boreo-subarctic species examined.

Perhaps the most obvious manifestation of thermal sensitivity of southern New England nudibranchs is the lack of species inhabiting the intertidal zone. Only Alderia modesta occurs dependably in the intertidal zone. Acantbodoris pilosa, Ancula gibbosa, and Polycera dubia may be found in the lowest part of the intertidal zone in the spring, but apparently cannot tolerate summer temperatures.

The extremes of marine geographic ranges are generally controlled by temperature effects. In the west Atlantic, it appears that the southern limits of distribution are controlled by both the upper thermal limit of adult reproduction and the timedistance interaction of larval transport. At the extremes of the range, non-reproducing species may be present (e.g. Facelina bostoniensis at Noank, Connecticut). At the northern end of the range, the existence of a temperature regime high enough to stimulate larval settling and metamorphosis may be important, and nonreproducins populations of more southern species may be present. In both cases, annual repopulation may depend on unpredictable transport of allochthonous larve, and may account for reports of year-to-year fluctuation of populations.

Further study of nudibranch life cycles may prove valuable in the analysis of the interrelationships of energy budgets, zoogeography, and evolutionary forces. 


\section{SUMMARY}

1. The most abundant nudibranchs in southern New England are small aeolids and sacoglossans. These gastropods are characteristically sub-annual species with asynchronous growth, continuous egg production and recruitment. Growth of individuals is notably rapid for molluscs, and is probably related to the possession of cerata, which appear to be an adaptation permitting increased rates of assimilation and metabolism. These characteristics represent adaptations to transient food sources which appear early in the microsuccession of fouling communities. Larger species, almost entirely dorids, have slower growth, restricted periods of egg production, synchronous growth cycles, and lower metabolic rates. These feed on more stable, longlived food sources characteristic of later successional stages.

2. The cerata represent convergent adaptations in four major taxa (Sacoglossa, Dendronotacea, Arminacea, and Aeolidacea) permitting an increase in growth and nonhomeostatic respiration. This is accomplished by an increase in both respiratory and digestive surface area.

3. The major component of recruitment of nudibranch populations is due to allochthonously-produced larvae. This may be of great value in repopulation of areas similar to southern New England, where temperature instability may preclude survival of a population for more than a few months.

4. High thermal sensitivity is characteristic of most nudibranchs of the western Atlantic, as indicated by high $\mathrm{Q}_{10}$ values. This sensitivity does not always cause mortality in natural populations, but is related to the rapid changes in population activity, and may represent a further adaptation to prey-species' life cycles. The interaction of high thermal sensitivity and a wide environmental temperature range, however, does limit the zoogeographic ranges and accounts for the low species diversity of the west Atlantic littoral fauna. Thermal sensitivity also explains the scarcity of intertidal species in southern New England, and accounts for the vernal disappearance of a few species.

5. Most species have type 1 (planktotrophic) development, which is of value in dispersal to and exploitation of new fouling growths. Some evidence is given that the proportion of type 1 development is higher in the western Atlantic than in the eastern Atlantic, which may relate to a greater instability of food species.

6. The widely-reported sudden appearances of populations are due to arrival of large numbers of larvae, followed by rapid growth to visible size. A critical temperature may stimulate settling and metamorphosis.

7. Sudden disappearances of adult populations are due to several causes. Small exploitist species normally overgraze food supplies following peak recruitment periods. This leads to destruction of the microhabitat and reduction of absolute population size, with apparent disappearance of individuals. Annual species normally die following periods of egg production, probably due to physiological weakening caused by extreme gonad output.

Acknowledgements. I wish to acknowledge the advice and guidance of Dr. D. R. FRANZ and the technical advice of Dr. S. Y. Feng. I am also indebted to the Marine Sciences Institute of Northeastern University for the use of their facilities. This research was performed in 
satisfaction of the doctoral dissertation requirements at the University of Connecticut. Support was provided by an N.D.E.A. Fellowship and a grant-in-aid from the University of Connecticut Research Foundation. Part of the travel was funded by a National Science Foundation travel grant.

\section{LITERATURE CITED}

AldER, J. \& HANCOCK, A., 1845-1855. A monograph of the British nudibrandiate Mollusca. Ray Soc., London, $369 \mathrm{pp}$.

BALCH, F. N., 1908. Two interesting New England nudibranch records. Nautilus 22, 13.

BAYER, F. M., 1963. Observations on pelagic mollusks associated with the siphonophores Velella and Physalia. Bull. mar. Sci. Gulf Caribb. 13, 454-466.

BĚLEHRÁder, J., 1935. Temperature and living matter. Borntraeger, Berlin, 229 pp. (Protoplasma-Monographien. Vol. 8.)

Bleakney, J. S. \& BaIley, K. H., 1967. Rediscovery of the saltmarsh sacoglossan Alderia modesta Loven in eastern Canada. Proc. malac. Soc. Lond. 37, 347-349.

Chambers, L. A., 1934. Studies on the organs of reproduction in the nudibranchiate mollusks, with special reference to Embletonia fuscata Gound. Bull. Am. Mus. nat. Hist. 66, 599-641.

ClarK, K. B., 1971. Construction of a collecting device for small aquatic organisms and a method for rapid weighing of small invertebrates. Veliger 13, 364-367.

- \& FRANZ, D. R., 1969. Occurrence of the sacoglossan opisthobranch Hermaea dendritica Alder \& Hancock in New England. Veliger 12, 174-175.

Costello, D. P., 1938. Notes on the breeding habits of the nudibranchs of Monterey Bay and vicinity. J. Morph. 63, 319-381.

Darneli, R., 1970. Evolution and the ecosystem. Am. Zool. 10, 9-15.

Du Bots-Reymond Marcus, E., 1972. Notes on some opisthobranch gastropods from the Chesapeake Bay. Chesapeake Sci. 13, 300-317.

EmLeN, J. M., 1973. Ecology: an evolutionary approach. Addison-Wesley, Reading, Mass., $493 \mathrm{pp}$.

Franz, D. R., 1970. Zoogeography of northwest Atlantic opisthobranch molluscs. Mar. Biol. 7, $171-180$.

- \& Clark, K. B., 1972. A discussion of the systematics, reproductive biology, and zoogeography of Polycerella emertoni and related species. Veliger 14, 265-270.

Gonor, J. J., 1966. Feeding. In: Marine Biology. Ed. by W. J. EnMondson. N. Y. Acad. Sci., New York, 3, 1-313.

Grave, B. H., 1930. Natural History of Bugula flabellata at Woods Hole, Massachusetts. J. Morph. 49, 355-383.

GREENE, R. W., 1970. Symbiosis in sacoglossan opisthobranchs: functional capacity of symbiotic chloroplasts. Mar. Biol. 7, 138-142.

Haderlie, E. C, 1969. Marine fouling and boring organisms in Monterey Harbor-II. Second year of investigation. Veliger 12, 182-192.

HADFIELD, M. G., 1963. The biology of nudibrandh larvae. Oikos 14, 85-95.

Hopkins, S. H., 1957. Parasitism. In: Treatise on marine ecology and paleocology. Ed. by J. Hedgreth. Geol. Soc. Am., New York, 1, 413-428 (Mem. Geol. Soc. Am. 67).

Huvé, P., 1953. Etude experimentale du peuplement de surfaces rocheuses immergees, en Mediterranee occidentale. C. r. hebd. Séanc. Acad. Sci., Paris 236, 419-422.

Hyman, L., 1967. The invertebrates. McGraw Hill, New York, 6, 1-792.

Kepner, W., 1943. The manipulation of the nematocysts of Pennaria tiarella by Aeolis pilata. J. Morph. 73, 297-311.

LANCE, J. R., 1961. A distributional list of southern California opisthobranchs. Veliger 4, 65-69.

LEMCHE, H., 1938. Gastropoda Opistbobranchiata. Zoology Iceland 4 (61), 1-54.

- 1941. Gastropoda Opistbobranchiata. The Godthaab expedition 1928. Meddr. Gronland $121(7), 1-65$. 
Loveland, R. E., Hendler, G. \& NewKIRK, G., 1969. New records of nudibrands from New Jersey. Veliger 11, 418-420.

MacArThUr, R., 1955. Fluctuations of animal populations, and a measure of community stability. Ecology 36, 533-536.

MacDougali, K. D., 1943. Sessile marine invertebrates of Beaufort, North Carolina. Ecol. Monogr. 13, 323-374.

Marcus, E., 1956. On two sacoglossan slugs from Brazil. Am. Mus. Novit. 1796, 1-21.

- 1961a. Opisthobranchia from North Carolina. J. Elisha Mitchell scient. Soc. 77, 141-151.

- 1961b. Opisthobranch mollusks from California. Veliger 3 (Suppl.), 1-84.

- \& Du Boss-Rermond, E., 1970. Opisthobranchs from Curacao and faunistically related regions. Stud. Fauna Curaçao 33, 1-129.

Minerkovsky, S. A., 1960. About the range of dispersal of pelagic larvae of bottom invertebrates with marine currents. Dokl. Akad. Nauk. SSSR, 135.

Millar, R. H., 1971. The biology of ascidians. Adv. mar. Biol. 9, 1-101.

Mrleer, M. C., 1961. Distribution and food of the nudibranchiate Mollusca of the south of the Isle of Man. J. Anim. Ecol. 30, 95-116.

- 1962. Annual cycles of some Manx nudibranchs, with a discussion of the problem of migration. J. Anim. Ecol. 31, 545-569.

Moore, H. B., 1939. The colonization of a new rocky shore at Plymouth. J. Anim. Ecol. 8, 29-38.

Morse, M., 1909. The autonomy of the hydranth of Tubularia. Biol. Bull. mar. biol. Lab., Woods Hole 16, 172-182.

Morse, M. P., 1968. Functional morphology of the digestive system of the nudibranch mollusc Acanthodoris pilosa. Biol. Bull. mar. biol. Lab., Woods Hole 134, 305-319.

- 1969. Contributions to the knowledge of New England nudibranchs. A. Rep. Am. malac. Union, $1969,18$.

NYBAKKEN, J., 1974. A phenology of the smaller dendronotacean, arminacean and aeolidacean nudibranchs at Asilomar State Beach over a twentyseven month period. Veliger 16, 370-373.

Orton, J. H., 1914. Preliminary account of a contribution to an evaluation of the sea: the life history of Galvina picta. J. mar. biol. Ass. U. K. 10, 323-324.

PotTs, G. W., 1970. The ecology of Onchidoris fusca (Nudibranchia). J. mar. biol. Ass. U. K. 50, 269-292.

RAO, K. V., 1937. Structure, habits, and early development of a new species of Stiliger EHRENBERG. Rec. Indian Mus. 39, 435-464.

RAsmussen, E., 1944. Faunistic and biological notes on marine invertebrates I. Vidensk. Meddr dansk naturh. Foren. 107, 207-233.

Renn, C. E., 1936. The wasting disease of Zostera marina I. A phytological investigation of the diseased plant. Biol. Bull. mar. biol. Lab., Woods Hole 70, 148-158.

Risso-Dominguez, C. J., 1963. Measuring nudibranchs: A standardization for descriptive purposes. Proc. malac. Soc. Lond. 35, 193-302.

Robilltard, G., 1971. The systematic and some aspects of the ecology of the genus Dendronotus. Veliger 12, 433-479.

Russeld, H. D., 1964. New England nudibranch notes. Nautilus 78, 37-42.

SANDERS, H. L., 1968. Marine benthic diversity: a comparative study. Am. Nat. 102, 243-282.

- 1969. Benthic marine diversity and the stability-time hypothesis. Brookhaven Symp. Biol. $22,71-81$.

Schezr, B. T., 1945. The development of marine fouling communities. Biol. Bull. mar. biol. Lab., Woods Hole 89, 103-121.

Schmekel, L., 1968. Ascoglossa, Notaspidea und Nudibranchia im Litoral des Golfes von Neapel. Revue suisse Zool. 75, 103-155.

SMirH, A. G. \& Gordon, M., 1948. The marine molluscs and brachiopods of Monterey Bay, California, and vicinity. Proc. Calif. Acad. Sci. (Ser. 4) 26, 147-245.

Stebbing, A. R. D., 1971. The epizoic fauna of Flustra foliacea. J. mar. biol. Ass. U. K. 51, $283-300$. 
- 1973. Competition for space between the epiphyres of Fucus serratus. J. mar. biol. Ass. U. K. 53, 247-261.

Swennen, C., 1959. The Netherlands coastal waters as an environment for Nudibranchia. Basteria 23 (Suppl.), 56-62.

- 1961. Data on distribution, reproduction, and ecology of the nudibranchiate molluses occuring in the Netherlands. Neth. Jl Sea Res. 1191-1240.

T'Hompson, T. E., 1958. The natural history, embryology, larval biology and post-larval development of Adalaria proxima (Alder \& HANCOCK) (Gastropoda Opisthobranchia). Phil. Trans. R. Soc. (B) 242, 1-58.

- 1961a. The structure and mode of functioning of the reproductive organs of Tritonia hombergi (Gastropoda Opisthobranchia). Q. Jl microsc. Sci. 102, 1-14.

- 1961b. Observations on the life history of the nudibranch Oncbidoris muricata (Mulner). Proc. malac. Soc. Lond. 34, 239-242.

- 1964. Grazing and the life cycles of British nudibranchs. Symp. Br. ecol. Soc. 4, 275-297.

- 1967. Direct development in a nudibrand, Cadlina laevis, with a discussion of developmental processes in Opisthobranchia. J. mar. biol. Ass. U. K. 47, 1-22.

THorson, G., 1966. Some factors influencing the recruitment and establishment of marine benthic communities. Neth. J1 Sea Res. 3, 267-293.

Turner, C. H., Ebert, E. E. \& Grven, R. R., 1969. Man-made reef ecology. Fish Bull. Calif. $146,1-221$.

WINCKWORTH, R., 1932. The British marine Mollusca. J. Cond., Lond. 19, 211-252.

- 1951. A list of the marine Mollusca of the British Isles: Additions and corrections. J. Conch., Lond. 23, 131-134.

Author's address: Dr. K. B. ClakK

Biological Sciences Department

Florida Institute of Technology

Melbourne, Florida 32901

USA 